\title{
Study of the morphological affinity between two species of benthic foraminifera from restricted environments: Rosalina douvillei (Cushman, 1928) and Trichohyalus aguayoi (Bermúdez, 1935)
}

\author{
Alicia GINER-BAIXAULI*, Juan USERA \& Jordi GUILLEM
}

Departamento de Botánica y Geología, Universitat de València, C/ Dr. Moliner, 5046100 Burjassot, Spain; aliciaginer@gmail. com; Juan.usera@uv.es; Jorge.Guillem@uv.es

* Corresponding author

Giner-Baixauli, A., Usera, J. \& Guillem, J. 2017. Study of the morphological affinity between two species of benthic foraminifera from restricted environments: Rosalina douvillei (Cushman, 1928) and Trichohyalus aguayoi (Bermúdez, 1935). [Estudio de la afinidad morfológica entre dos especies de foraminíferos bentónicos de ambientes restringidos: Rosalina douvillei (Cushman, 1928) y Trichohyalus aguayoi (Bermúdez, 1935)]. Spanish Journal of Palaeontology, 32 (2), 313-330.

\section{ABSTRACT}

A biometric comparison is carried out on selected tests of the foraminiferal species Rosalina douvillei (Cushman, 1928) and Trichohyalus aguayoi (Bermúdez, 1935). The Rosalina douvillei specimens were recovered from the marginal marine Oligocene/Miocene site of Rüssingen (Mainz Basin, Germany), the lacustrine beds of the lower Miocene site of Buñol (Valencian Community, Spain) and the middle/ upper Miocene site of Fuendetodos (Aragón, Spain). The Trichohyalus aguayoi tests were collected in the current coastal lagoon of Torreblanca and recovered from Holocene cores sampled in the Peñíscola marsh and in the coastal lagoon of 1'Albufera de València, all them in the Valencian Community (Spain). In addition, the chronostratigraphic and geographical distribution of both species is also summarized. Trichohyalus aguayoi and Rosalina douvillei share many morphological characteristics but the measured specimens of Trichohyalus aguayoi are characterized by generally larger sizes, narrower and more elongate chambers and a higher number of chambers in the outer whorl. The Rosalina douvillei specimens from Fuendetodos are as large as Trichohyalus aguayoi and show particularly high chamber size increase rates but also few and less elongate chambers

\section{RESUMEN}

Se ha realizado un estudio biométrico de los caparazones de las especies de foraminíferos Rosalina douvillei (Cushman, 1928) y Trichohyalus aguayoi (Bermúdez, 1935). Los ejemplares de Rosalina douvillei fueron recuperados en los depósitos de ambiente costero marginal del yacimiento de Rüssingen (Oligoceno/Mioceno, cuenca de Maguncia, Alemania), de las capas lacustres del yacimiento de Buñol (Mioceno inferior, Comunidad Valenciana) y del yacimiento de Fuendetodos (Mioceno medio/superior, Aragón). Los ejemplares de Trichohyalus aguayoi fueron recolectados en la laguna costera actual de Torreblanca, en sondeos holocenos practicados en la marjal de Peñíscola y en la Albufera de Valencia (las tres localidades se hallan en la Comunidad Valenciana). Además, también se resume la distribución cronoestratigráfica y geográfica de ambas especies. Trichohyalus aguayoi y Rosalina douvillei comparten muchas características morfológicas pero los especímenes medidos de Trichohyalus aguayoi se caracterizan por tamaños en general más grandes, cámaras más alargadas y estrechas y un mayor número de cámaras en la última vuelta. Los ejemplares de Rosalina douvillei de Fuendetodos son tan grandes como Trichohyalus aguayoi y muestran tasas de incremento del tamaño de las 
in the last whorl. The number and shape of chambers in the last whorl seem thus to be controlled at least in part by hereditary factors. The morphological affinity between the two species probably constitute an example of convergence derived from similar environmental conditions but further research is required to discard phylogenetic proximity.

Keywords: Rosalina douvillei, Trichohyalus aguayoi, Foraminifera, morphological affinity.

\section{INTRODUCTION}

The interpretation of skeletal structures in fossil species has been extensively developed by some authors (e.g., Raup \& Stanley, 1971) and their functional significance has also been widely treated in foraminifera (e.g., Hottinger, 1978, 2000; Haynes, 1981; Hallock et al., 1991). When comparing phylogenetically closely related taxa it can be proposed that similar structures are homologous (i.e., they have identical ontogenetic origin) and have an equal function. However, if this phylogenetic relationship does not seem so clear, we can still argue that this structure could have the same or a similar function, an aspect that we call homoplasia.

Rosalina douvillei (Cushman, 1928) and Trichohyalus aguayoi (Bermúdez, 1935) are two species of benthic foraminifera with morphological similarity. Both are typical of restricted environments, but they are separated in time by about 5 million years. These species belong to different genera, so their similar form is possibly due to a process of convergence and adaptation to a particular environment. In both taxa the presence of a system of calcareous plates occupying the umbilical region is observed in the macrospheric form. In $R$. douvillei the macrospheric and the cámaras particularmente altas pero también un bajo número de cámaras poco alargadas en la última vuelta. El número y forma de las cámaras en la última vuelta parece pues estar controlado, al menos en parte, por factores hereditarios. La afinidad morfológica entre las dos especies probablemente constituye un ejemplo de convergencia derivada de la similitud de condiciones ambientales pero son necesarios más estudios para poder descartar una proximidad filogenética.

Palabras clave: Rosalina douvillei, Trichohyalus aguayoi, foraminíferos, afinidad morfológica. microspheric forms can be distinguished by the complexity in the secondary openings of the umbilical side. In $T$. aguayoi only the macrospheric form is known.

The aim of this study is to carry out a biometric comparison between the two species in order to quantify their morphological similarities and differences. This provides data to discern which characters can be considered of taxonomic significance and which ones might be attributed to other factors like habitat, environment or life style.

\section{MATERIAL AND METHODS}

A comparative biometric analysis was carried out on wellpreserved tests of $T$. aguayoi and $R$. douvillei recovered from the $>125 \mu \mathrm{m}$ size-fraction of samples collected in six different localities in western Europe, in Spain and Germany (Fig. 1) and available at the University of València. For each locality, 25 specimens of $T$. aguayoi or $R$. douvillei were randomly selected (e.g., by using random numbers to select files and rows of foraminifers fixed to storage slides, etc.) from samples rich in any one of the two species.
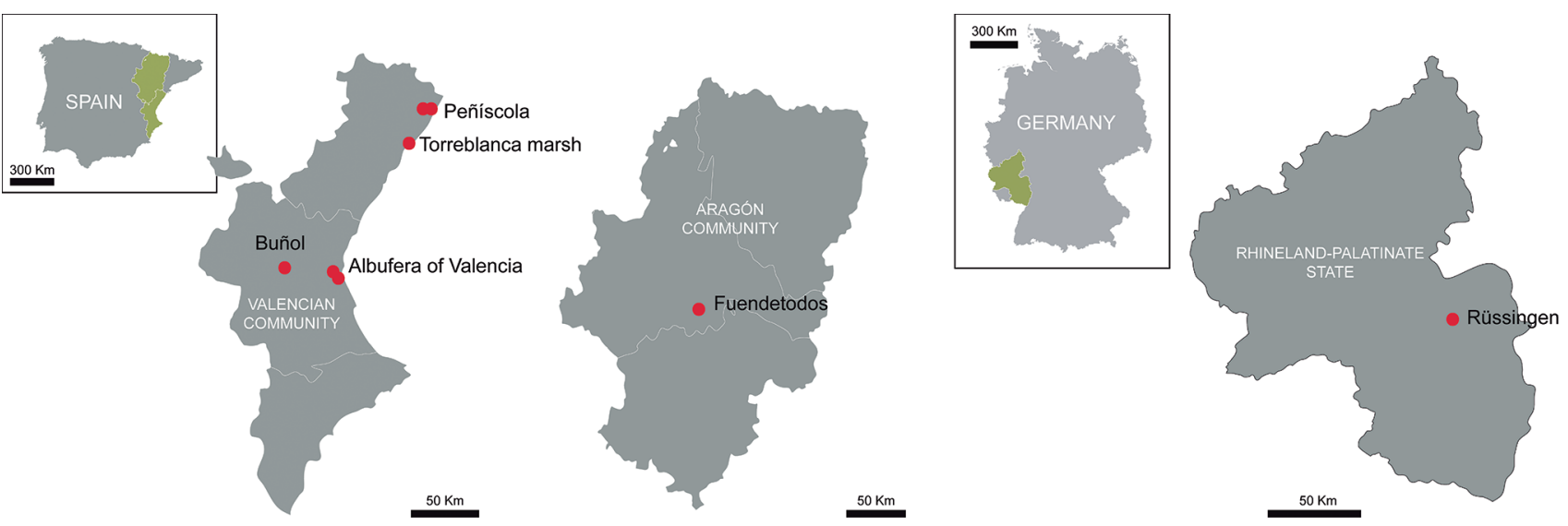

Figure 1. Geographic location of sampling sites. 
The $R$. douvillei specimens were obtained from the following sites:

1) Rüssingen (Mainz, Germany). The specimens of $R$. douvillei were selected in samples (Gö-1, Gö-4, and Gö$10)$ recovered in the Rüssingen quarry, in the community of Göllheim (Mainz, Rheinland-Pfalz, Germany). Rüssingen (about $43 \mathrm{~km} \mathrm{SSW}$ from Mainz, N 49 $37^{\prime} 22.4^{\prime \prime}$, E $8^{\circ}$ $\left.5^{\prime} 25.32^{\prime \prime}\right)$ is located in the southwestern margin of the Mainz Basin, which constitutes one of the structural units of the Rhine rift-graben system that developed during the Palaeogene and connected the North Sea Basin with the Tethys area (Rothausen \& Sonne, 1988). From the early Chattian (upper Oligocene) to the Aquitanian (lower Miocene) the Mainz Basin, together with other adjacent marginal marine areas, became increasingly isolated from both the north Germany and the western Paratethys basins (Gebhardt, 2003). The selected foraminifera were collected close to the Oligocene/Miocene boundary in the Rüssingen quarry (in the so-called Obere Cerithienschichten and Corbicula-Schichten Beds, see Kadolsky, 1988) and the assemblages show a progressive impoverishment in diversity, probably reflecting a gradual change from brackish to freshwater conditions (Bernabé et al., 1991).

2) Buñol (Valencia, Spain). The specimens of $R$. douvillei come from samples (BÑ-1, BÑ-2bis, and BÑ5) collected in the Miocene athalassic lacustrine basin of Buñol (Valencia, Spain, N 39 24'53.867', W $0^{\circ}$ 47 '35.462"). The site of Buñol is known mainly for its numerous fossil vertebrate remains (Made et al., 1998, and references therein) and has been dated as lower Aragonian, which is equivalent to the upper Burdigalian marine stage (Daams \& Freudenthal, 1981). The composition and ecological characteristics of its foraminiferal assemblages have been studied by Márquez \& Usera (1984, 1988).

3) Fuendetodos (Zaragoza, Spain). The lacustrine deposits of Fuendetodos are located in the central sector of the Iberian margin of the Ebro basin, south of the province of Zaragoza (Aragón, Spain). The stratigraphy of this site was studied by Pérez (1989), who differentiated three tectosedimentary units (Riba, 1989). It was in the upper unit TSU N3 ("Calcarenita de Fuendetodos") where species of different groups of marine affinity (foraminifera, ostracoda and molluscs) were found (Anadón, 1989). The foraminifera found in this site were reported by Usera et al. (1991a). Observations on ostracods and isotope data were later carried out in order to determine the paleoenvironment in which this marine-like fauna developed (Anadón, 1992; Anadón et al., 1997). The $R$. douvillei specimens employed in this study were recovered from three selected samples (FT-108, FT-112 and FT-119) in the site of Fuendetodos (N 41 16' 2.597', E $0^{\circ}$ 52' 3.928'”).

The specimens of $T$. aguayoi were obtained in the following localities:
1) Torreblanca marsh (Castellón, Spain). The current Torreblanca marsh results from the infilling process of a Holocene coastal lagoon. The extraction of peat for its industrial exploitation has given place to a system of ponds-lagoons affected by sea water leaks and with salinity fluctuations throughout the year depending on the distance between each pond and the coastline. The annual salinity range recorded in several ponds, approximately 6-14\%o (Guillem, 2007), corresponds to mesohaline waters. The presence in these ponds-lagoons of T. aguayoi was detected by Usera et al. (1990b) and Arco et al. (1991). A taphonomic, taxonomic and ecologic study of the foraminiferal assemblages can be found in Guillem (2007). Trichohyalus aguayoi is abundant in most surface samples in the Torreblanca ponds, where it constitutes the dominant foramineral species. The selected specimens were recovered from sample TB 3.8.1. (N 40 11'34.3", E $0^{\circ} 12$ '55.8”) near the bar separating the ancient coastal lagoon from the sea.

2) Albufera of Valencia (Valencia, Spain). The first data on the presence of $T$. aguayoi in the Albufera of Valencia come from the study of Robles et al. (1985), on the mollusc fauna of this natural site. Afterwards, surface sampling (Usera et al., 1990a) and surveys in different areas have been carried out, which have led to the study of different groups of organisms, including foraminifera (Usera et al., 2006a, 2007a, 2007b). No living foraminifera have been found in the current freshwater lagoon. The selected specimens of $T$. aguayoi were recovered from the upper section of two short cores, located close to each other (sample 66-65, core Centre: N 39 20' $12.85^{\circ}$ ", W $0^{\circ} 21^{\prime} 13.66^{\prime \prime}$ and sample 56-55, core L'Antina: N $39^{\circ}$ $\left.19^{\prime} 58.78^{\prime \prime} \mathrm{W}, 0^{\circ} 22^{\prime} 1.13^{\prime \prime}\right)$, where this species was most abundant.

3) Peñíscola (Castellón, Spain). The Peñíscola marsh is located about $25 \mathrm{~km}$ north from Torreblanca and it constitutes another example of the final sedimentary infilling phase of an ancient coastal lagoon. The evolution of its foraminiferal assemblages during the Holocene was studied by Usera et al. (2003, 2006b). The selected specimens of $T$. aguayoi were picked from samples PÑ119 and PÑ2-43, in which this species was particularly abundant, and which belong to two cores (core S1: $\mathrm{N} 40^{\circ}$ 21'52.58", E $0^{\circ} 23^{\prime} 59.69^{\prime \prime}$ and core S2: N $40^{\circ} 22^{\prime}$ '5.44", E $0^{\circ} 24$ ' 6.32") originally extracted by Usera et al. (2006b).

Although initially somewhat neglected (Scott, 1974), many biometrical studies of foraminiferal shells have already been developed, including those focused on particular species (e.g., only in small benthic foraminifera: Buzas, 1966; Corliss, 1979; Showers, 1980; Vénec-Peyré, 1983; Malmgren, 1984; Loubere et al., 1988; Gary et al., 1989; Collins, 1989; Caralp, 1989; Burgess \& Schnitker, 1990; Usera et al., 1991b; Hayward et al., 2004; Lehmann et al., 2006; among others). Nevertheless, no specific 
biometrical analysis of $R$. douvillei is known to us. Arnold (1954), and particularly Tufesco (1969) have provided quantitative data about $T$. aguayoi dimensions but the most complete available biometrical study focused on this species is that from Foresi et al. (2004). Following in part the latter authors, six basic parameters were measured in each specimen with an ocular micrometre installed in a Wild M-10 binocular microscope: length (L) and breadth (B) of the whole test and length and height of the second $\left(l_{2}, h_{2}\right)$ and third $\left(l_{3}, h_{3}\right)$ last chambers (Fig. 2). Some specimens (particularly in $R$. douvillei) had to be constantly kept in wet conditions while being measured due to their partial opacity. The number of chambers in the last whorl was also noted for each test. A comparison between the two species was subsequently made, based on the biometric data. Additionally, a one-way analysis of variance (ANOVA) test was carried out in order to explore the significance of differences between localities. All statistical tests were done using the PAST software package (see Hammer \& Harper, 2006 for procedures).

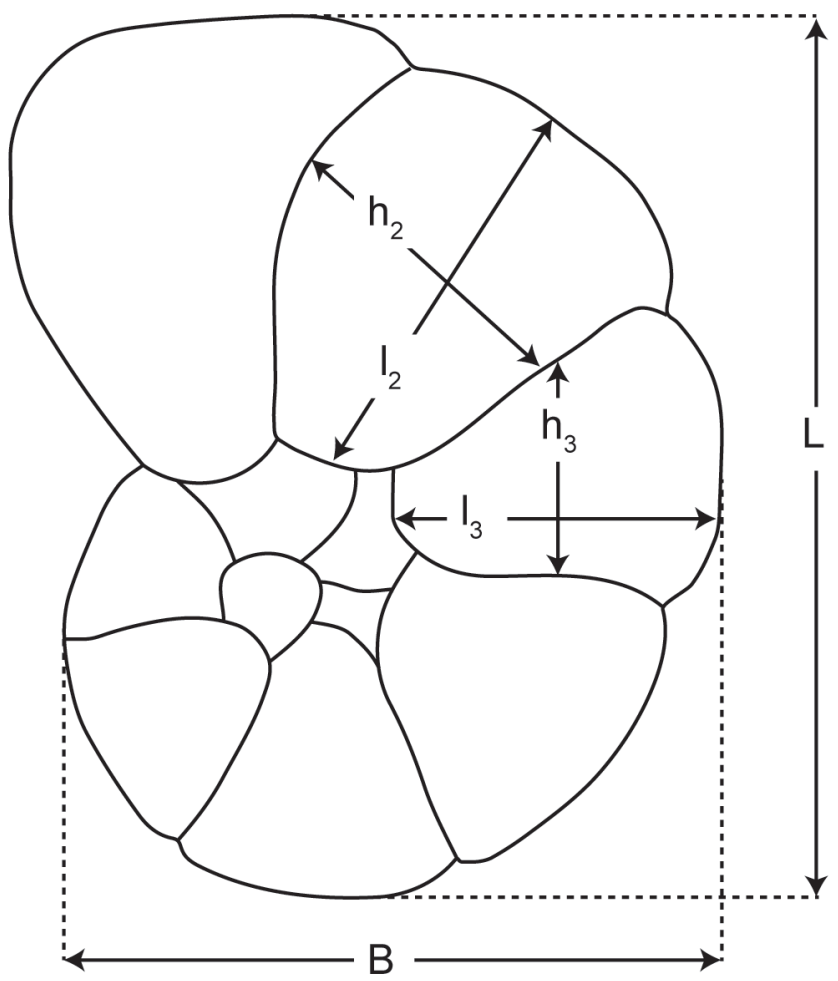

Figure 2. Biometrical parameters measured in T. aguayoi and $R$. douvillei. L: test length = largest diameter; B: test breadth (orthogonal to the largest diameter); $1_{2}, 1_{3}$ : length of the second and third last chambers; $h_{2}, h_{3}$ : height of the second and third last chambers. Simplified from Foresi et al. (2004).

\section{SYSTEMATIC PALAEONTOLOGY}

Kingdom CHROMISTA Cavalier-Smith, 2010

Subkingdom HAROSA Burki et al., 2007

Infrakingdom RHIZARIA Cavalier-Smith, 2002

Phylum FORAMINIFERA d'Orbigny, 1826

Class GLOBOTHALAMEA Pawlowski, Holzmann \& Tyszka, 2013

Order ROTALIIDA Delage \& Hérouard, 1896

Superfamily DISCORBOIDEA Ehrenberg, 1838

Family Rosalinidae Reiss, 1963

Genus Rosalina d'Orbigny, 1826

Rosalina douvillei (Cushman, 1928)

(Figs. 3a-f)

1928 Discorbis douvillei Cushman, p. 54, Pl. 3, fig. 1. 1958 Discorbis globularis (d'Orbigny), Batjes, p. 145, Pl. 7, fig. 2.

1966 Discorbis douvillei Cushman, Le Calvez, p. 409, Pl. 2, figs. 3-7.

1970 Rosalina douvillei (Cushman), Le Calvez, p. 140141, Pl. 29, figs. 3-5.

1983 Rosalina douvillei (Cushman), Setiawan, p. 115, Pl. VIII, fig. 2.

1984 Rosalina douvillei (Cushman), OdrzywolskaBienkowa \& Pozaryska, p. 133-134, Pl. 6, fig. 7.

1984 Rosalina douvillei (Cushman), Márquez \& Usera, p. 226, Pl. 1, figs. 2 a-c, Pl. 2, figs. 1 a-c, 2 a-c.

Description. The original description of Cushman (1928) is as follows (translation from French is ours): "Test flat-convex; the dorsal side forms a wide and low spire. Ventral side flat or slightly concave, periphery rounded; chambers very differentiated, slightly inflated; dorsal sutures oblique, ventral sutures very shallow; wall smooth on the dorsal side, finely perforated on the ventral side with particular protuberances protruding towards the umbilical region; opening ventral with a broad border."

Occurrence. Rosalina douvillei is a brackish water species that has been found in the upper Eocene (Priabonian) of northern Italy (Setiawan, 1983; Barbin \& Keller-Grünig, 1991 ) and Poland (Odrzywolska-Bienkowa \& Pozaryska, 1984), in the lower Oligocene of the Paris Basin and in Belgium (Batjes, 1958; Le Calvez, 1966, 1970), in the upper Oligocene of Aquitaine (Andreieff et al., 1974), in the Oligocene-Miocene boundary of the Mainz Basin in Germany (Bernabé et al., 1991), in the lower Miocene of Buñol (Márquez \& Usera, 1984, 1988) and finally in the 


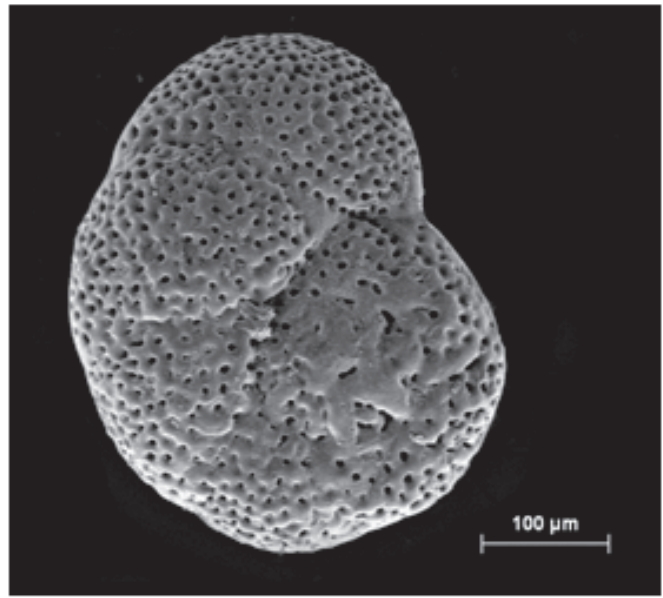

a

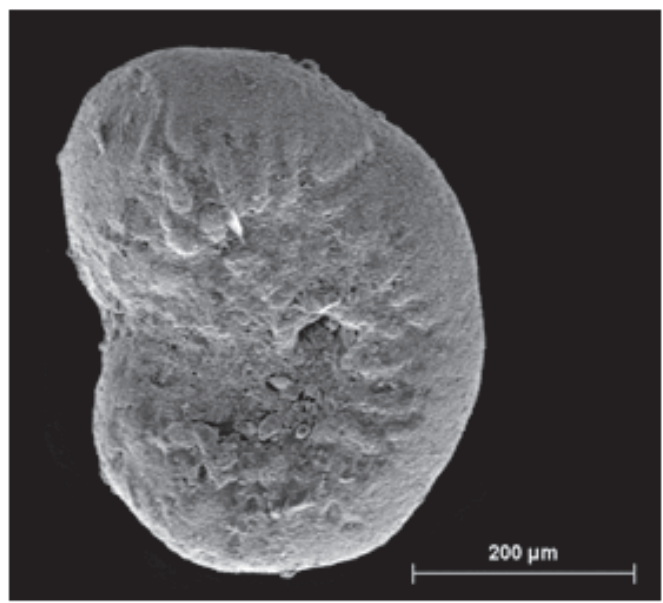

C

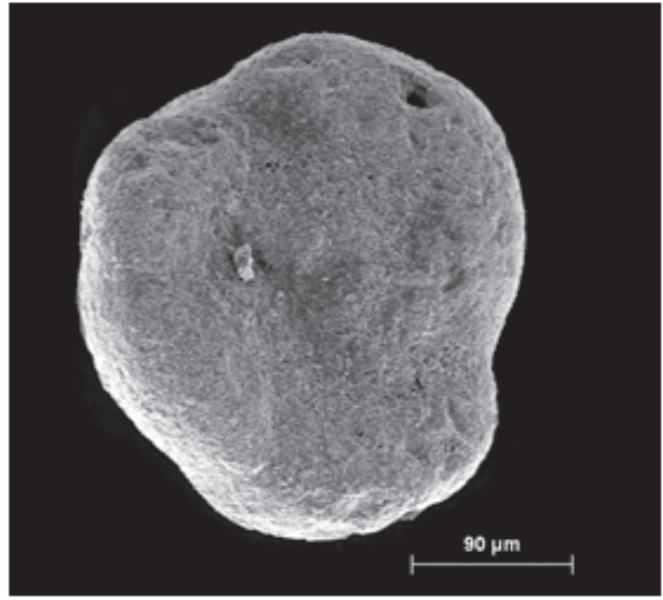

e

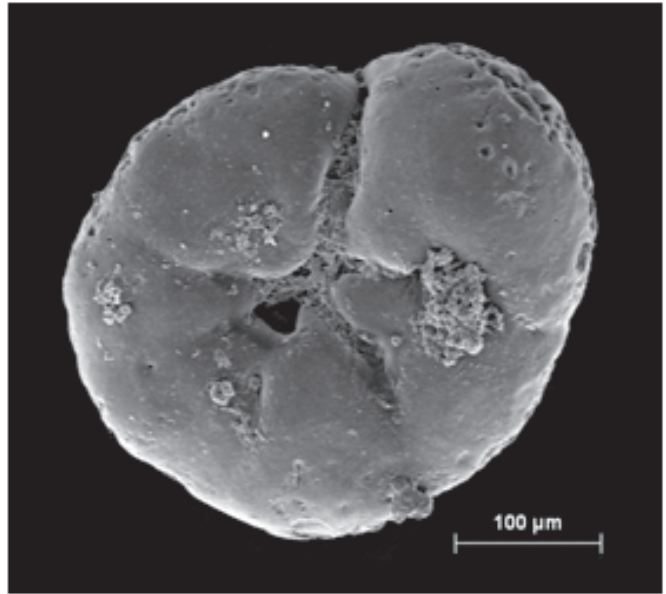

b

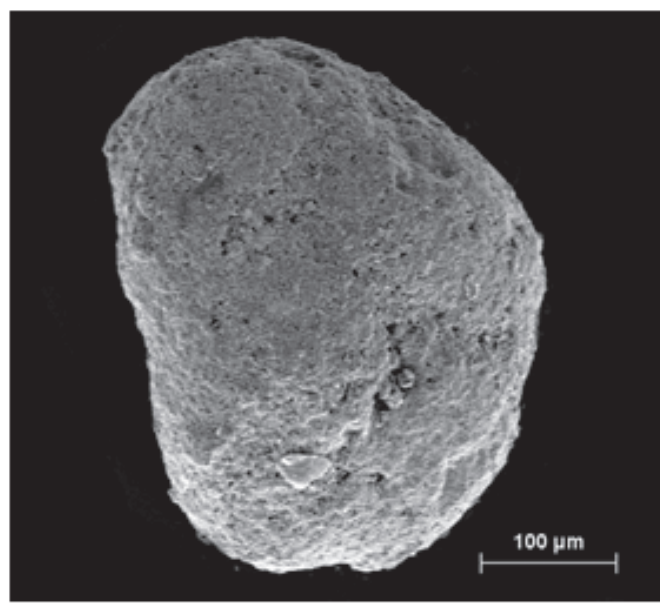

d

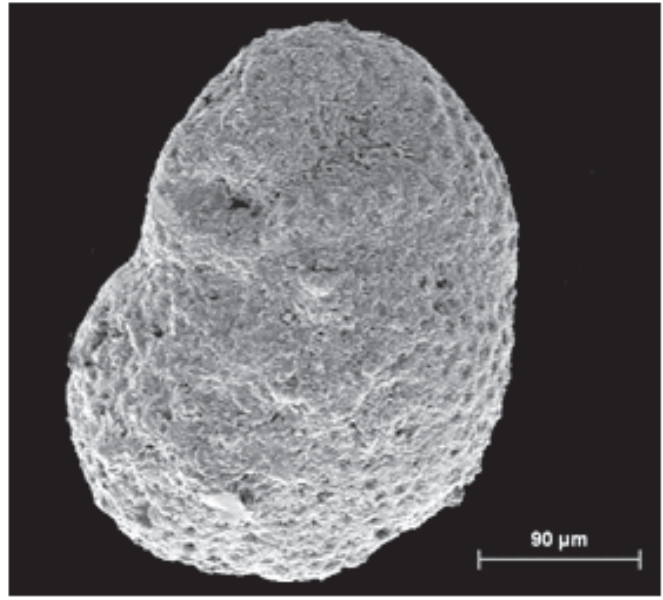

f

Figure 3. a) Rosalina douvillei (Cushman, 1928). Buñol. Spiral view. Microspheric form. Lower Miocene. b) Rosalina douvillei. Buñol. Umbilical view. Macrospheric form. Lower Miocene. c) Rosalina douvillei. Fuendetodos. Umbilical view. Macrospheric form. Middle/upper Miocene. d) Rosalina douvillei. Fuendetodos. Spiral view. Macrospheric form. Middle/upper Miocene. e) Rosalina douvillei. Rüssingen. Umbilical view. Macrospheric form. Upper Oligocene/lower Miocene. f) Rosalina douvillei. Rüssingen. Spiral view. Macrospheric form. Upper Oligocene/lower Miocene. 
middle/upper Miocene of the Ebro Basin (Anadón, 1989, 1992; Usera et al., 1991a; Anadón et al., 1997).

\section{Superfamily CHILOSTOMELLOIDEA Brady, 1881}

Family Trichohyalidae Saidova, 1981

Genus Trichohyalus Loeblich \& Tappan, 1953

Trichohyalus aguayoi (Bermúdez, 1935)

(Figs. 4a-f)

1935 Discorbis aguayoi Bermúdez, p. 204, Pl. 15, figs. 10-15.

1954 Discorinopsis aguayoi (Bermúdez), Arnold, p. 4-13, Pl. 1, figs. 2-10, Pl. 2, figs. 1-17.

1968 Trichohyalus tropicus (Bermúdez), Albani, p. 117, Pl. 10, figs. 13-14.

1969 Trichohyalus aguayoi (Bermúdez), Tufesco, p.47, figs. 1-2.

1974 Lamellodiscorbis aguayoi (Bermúdez), Resig, p. 75, Pl. 1, figs. 15-16.

1979 Discorinopsis aguayoi (Bermúdez), Scott et al., p. 257, Pl. 16, figs. 1-2.

1983 Discorinopsis aguayoi (Bermúdez), Boltovskoy \& Hincapié de Martínez, p. 218, Pl. 2, figs. 8-9.

1990 Discorinopsis aguayoi (Bermúdez), Scott et al., p. 730, Pl. 1, figs. 6 a-b.

1991 Discorinopsis aguayoi (Bermúdez), Scott et al., p.385, Pl. 2, figs. 17-18.

1991 Trichohyalus lacunae (Silvestri), Albani et al., p. 34, Pl. 1, figs. 9-10.

1997 Trichohyalus aguayoi (Bermúdez), García-Forner, p. 108 , Pl. 18 , fig. 6 , Pl. 19, fig. 1.

2003 Discorinopsis aguayoi (Bermúdez), Javaux \& Scott, p. 14, figs 6-1, 6-2.

2004 Discorinopsis aguayoi (Bermúdez), Foresi et al., p. 326-329, Pl. 1, figs. 1-10, Pl. 2, figs. 1-11, Pl. 3, figs. 1-12, Pl. 4, figs. 1-13.

2005 Trichohyalus aguayoi (Bermúdez), Blázquez, p. 113, Pl. 10, fig. 6, Pl. 11, fig. 1.

2007 Trichohyalus aguayoi (Bermúdez), Guillem, p. 135-140, Pl. XVI, figs. 4-6, Pl. XVII, figs. 1-4, Pl. XXII, figs. 2, 4-6, Pl. XXIII, fig. 4, Pl. XXIV, figs. 3-4, Pl. XXV, figs. 1-2, Pl. XXVI, figs. 1-6, Pl. XXVIII, fig. 2, Pl. XXIX, figs. 4-6, Pl. XXX, figs. 5-6, Pl. XXXI, figs. 2-5.

Description. The original description of this species by Bermúdez (1935) is (translation from Spanish is ours): "Test vitreous, slightly trochoid, outline circular peripheral, smoothly lobed; margin rounded; dorsal side formed by numerous subglobular chambers; ten chambers in the last whorl, perforated by numerous remarkable holes; sutures limbate in the first whorls, depressed in the last whorl; all sutures limbate in some specimens; proloculus visible on the dorsal side: ventral side flat, with a large vitreous callus that occupies almost the entire surface; this callus is formed by a plate with radial riblets and rugosities, not reaching the lateral edge of the chambers; in specimens that have lost the last chamber wall it can be seen that this callus is partly free, forming a vitreous wall. Light brown coloured. Aperture a slit at the base of the last chamber, in contact with the whorl edge; broken specimens show inner chambers openings as a half-moon shape on the ventral edge of the whorl."

Occurrence. Trichohyalus aguayoi was originally described in littoral waters in Cuba (Bermúdez, 1935) and later reported in different brackish environments in the Caribbean and the Gulf of Mexico (Arnold, 1954; Boltovskoy \& Hincapié de Martínez, 1983; Scott et al., 1991), in the Mediterranean and the Black Sea (Tufesco, 1969, 1973; Lévy, 1982; Albani et al., 1991; Zampi et al., 1996; Foresi et al., 2004), in the Atlantic (Javaux \& Scott, 2003) and the Pacific coast of North America (Murray, 1991), in Hawaii (Resig, 1974), in South America (Boltovskoy \& Vidarte, 1977; Scott et al., 1990) or even in Australia (Albani, 1968), where a very similar species, possibly co-specific with $T$. aguayoi, Trichohyalus tropicus (Collins, 1958), has also been found in non-marine saline lakes (Cann \& De Dekker, 1981). In the Iberian Peninsula, this species is limited to the Mediterranean area and has been reported living in the Ebro Delta (Usera et al., 1989; Cearreta et al., 2016) in the Santa Pola Salinas (Zaninetti, 1984) or in the Torreblanca lagoon (Usera et al., 1990b; Arco et al., 1991; Guillem, 2007).

As a fossil, T. aguayoi has been detected as far back as in Messinian (upper Miocene) brackish lake deposits in Rosignano Marittimo by Foresi et al. (2004), who also report this species in Pliocene brackish lagoon sediments in Granaiolo (both localities in Tuscany, Italy). In the Iberian Peninsula it has been recorded in marsh or brackish lagoon Quaternary sediments, always in the Mediterranean area, in Catalonia (Calzada, 1970) or in the Valencian Community (Robles et al., 1985; Dupré et al., 1988; Mateu \& Viñals, 1990; García-Forner et al., 1993; Viñals et al., 1993; López Buendía, 1995; Usera et al., 1996, 2001, 2003, 2006b, 2012; García-Forner, 1997; Blázquez \& Ferrer, 2003; Usera, 2003; Blázquez \& Usera, 2004, 2005; Blázquez, 2005; Ferrer et al., 2005; Carmona et al., 2016).

\section{RESULTS}

The basic results of the biometric analysis are shown in Table 1. As a whole, the T. aguayoi specimens are significantly longer (Mann-Whitney's $\mathrm{U}, p=0.001$ for 


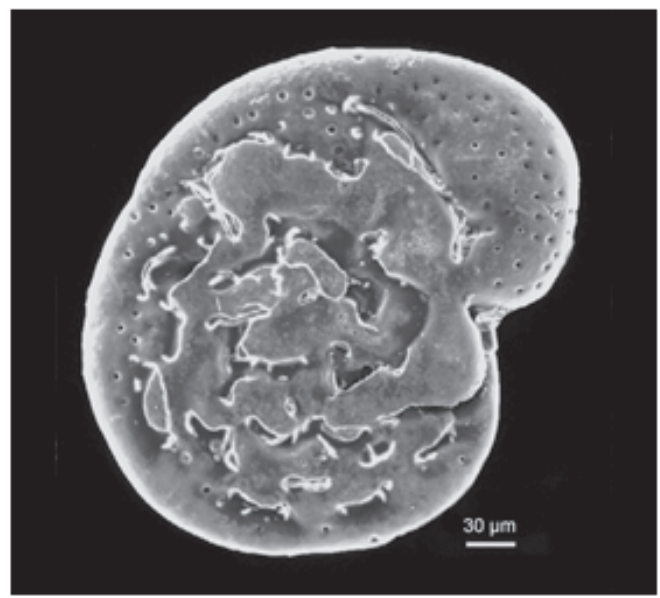

a

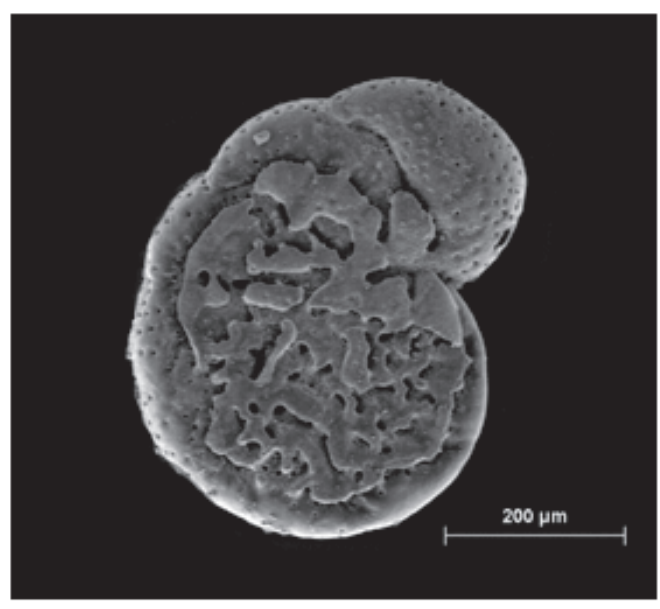

C

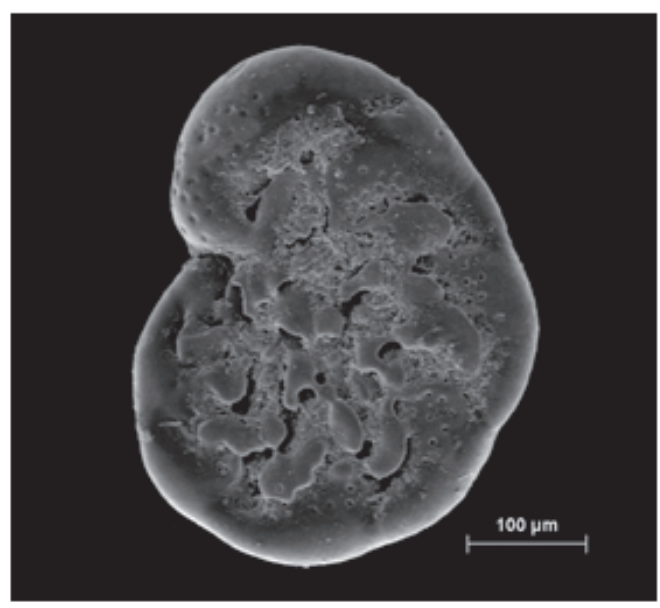

e

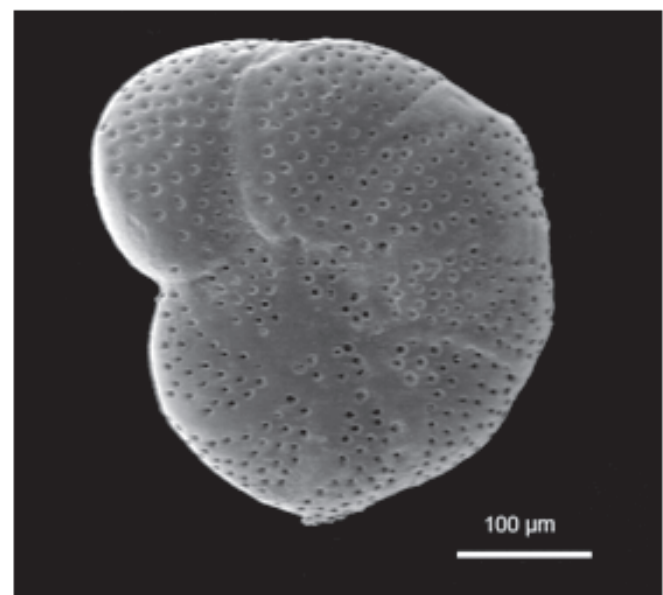

b

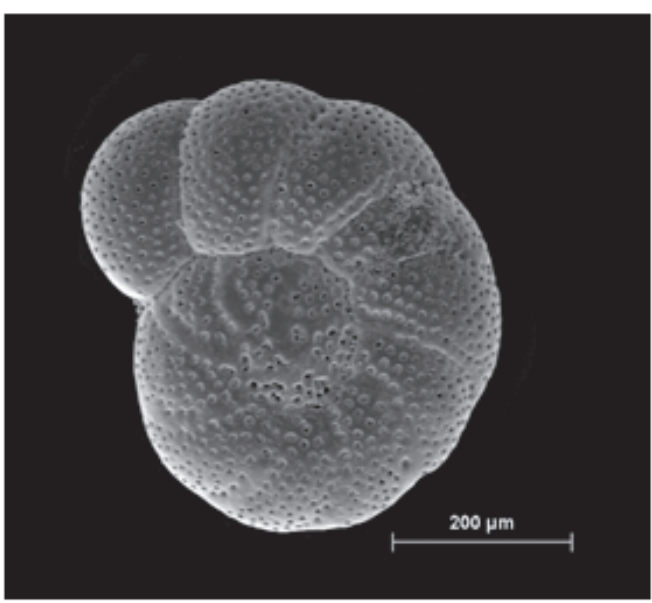

d

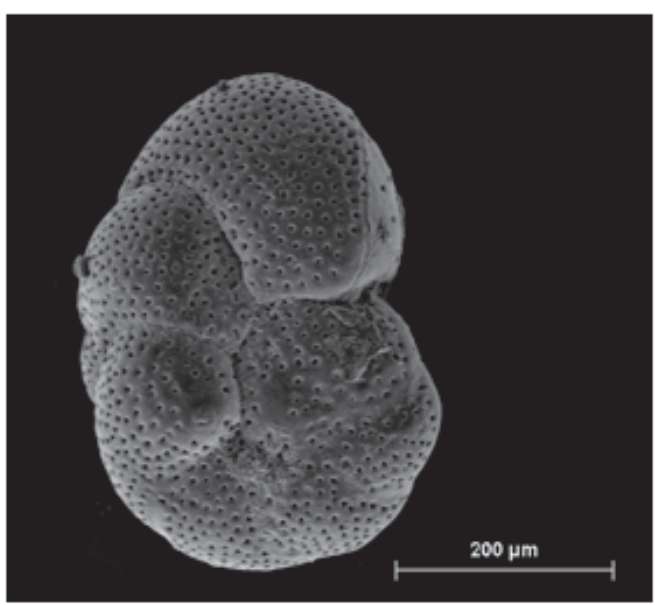

f

Figure 4. a) Trichohyalus aguayoi (Bermúdez, 1935). Peñíscola. Umbilical view. Macrospheric form. Holocene. b) Trichohyalus aguayoi. Torreblanca. Spiral view. Macrospheric form. Recent. c) Trichohyalus aguayoi. Torreblanca. Umbilical view. Macrospheric form. Recent. d) Trichohyalus aguayoi. Torreblanca. Spiral view. Macrospheric form. Recent. e) Trichohyalus aguayoi. Albufera of Valencia. Umbilical view. Macrospheric form. Holocene. f) Trichohyalus aguayoi. Albufera of Valencia. Spiral view. Macrospheric form. Holocene. 
test length $\mathrm{L}$ ) than the $R$. douvillei selected ones, and they are generally wider, although the difference in measured test breadth (B) is only significant at a $95 \%$ confidence level (Mann-Whitney's U, $p=0.011$ ). Nevertheless, both parameters strongly co-vary in a very similar way in the two species $\left(\mathrm{r}^{2}=0.970\right.$ and 0.935 for $T$. aguayoi and $R$. douvillei, respectively, with a $p \approx 0$ in both cases) (Fig. 5). Trichohyalus aguayoi is also characterised by longer second and third last chambers (e.g., averages values $1_{2}=$ 137 and $1_{3}=121 \mu \mathrm{m}$ in T. aguayoi vs. $1_{2}=108$ and $1_{3}=$ $84 \mu \mathrm{m}$ in R. douvillei; Mann-Whitney's $\mathrm{U}, p=2.05 \times 10^{-5}$ for $1_{2}$ and $p=4.33 \times 10^{-8}$ for $l_{3}$ ) (Table 1 ). In contrast, the third last chamber height $\left(\mathrm{h}_{3}\right)$ is fairly equal in both species and the second last chamber is even slightly higher in $R$. douvillei (Mann-Whitney's $\mathrm{U}$ for $\mathrm{h}_{2}, p=0.045$ ), particularly in the specimens from Fuendetodos (Table 1; Figs. 6-7).

Therefore, T. aguayoi can be distinguished from $R$. douvillei by more elongate chambers and generally higher length: height $\left(l_{2} / h_{2}\right.$ and $\left.l_{3} / h_{3}\right)$ ratios (Fig. 8). Average values are significantly higher for T. aguayoi $\left(\mathrm{l}_{2} / \mathrm{h}_{2}=1.682\right.$ and $\mathrm{l}_{3} / \mathrm{h}_{3}$ $=1.489)$ than for $R$. douvillei $\left(\mathrm{l}_{2} / \mathrm{h}_{2}=1.177\right.$ and $\mathrm{l}_{3} / \mathrm{h}_{3}=$ 1.073; Mann-Whitney's $\mathrm{U}, p \approx 0$ ). Length and height exhibit a moderate but still significant positive correlation for both the second $\left(\mathrm{r}^{2}=0.476\right.$ for T. aguayoi and 0.629 for $R$. douvillei, $\left.p=8.35 \cdot 10^{-12}\right)$ and the third $\left(\mathrm{r}^{2}=0.744\right.$ for T. aguayoi and 0.531 for $R$. douvillei, $p=1.12 \times 10^{-13}$ ) last chambers.

The measured tests can also be distinguished by the number of chambers in the last whorl. In T. aguayoi, this parameter ranges from 5 to 10 , although most individuals show 7-8 chambers. In $R$. douvillei, they vary between 4 and 8 but the large majority of tests exhibit 5-6 chambers (Fig. 9). The difference between the mean values in the two species ( 7.63 for $T$. aguayoi and 5.76 for $R$. douvillei) is again highly significant (Mann-Whitney's $\mathrm{U}, p \approx 0$ ). This is clearly linked to the aforementioned difference in chamber shape $\left(l_{2} / h_{2}\right.$ and $l_{3} / h_{3}$ ratios $)$ since more chambers per whorl involve less space for each one of them.

Additional parameters were calculated basing on the metric measurements. The index of test curvature (L/B ratio), also represented in Figure 9, yields similar results for $T$. aguayoi (range $=1.11-1.49$, average $=1.26$ ) and $R$. douvillei (range $=0.90-1.38$, average $=1.21$ ) with slightly lower values for the latter. The chamber length and height increase rates $\left(l_{2} / l_{3}\right.$ and $h_{2} / h_{3}$ ratios $)$ are also comparable in both species, with strongly overlapping ranges (Fig. 10), although $R$. douvillei shows slightly higher average values $\left(\mathrm{l}_{2} / \mathrm{l}_{3}=1.32\right.$ for $R$. douvillei vs. 1.16 for $T$. aguayoi; and $\mathrm{h}_{2} /$ $\mathrm{h}_{3}=1.21$ for $R$. douvillei vs. 1.06 for T. aguayoi).

Table 1. Range (minimum and maximum) and average values of the seven basic parameters measured in T. aguayoi and R. douvillei tests recovered from the six selected localities. L: test length; B: test breadth; $1_{2}$ : length of second last chamber; $h_{2}$ : height of second last chamber; $1_{3}$ length of third last chamber; $h_{3}$ : height of third last chamber; nc: number of chambers in the last whorl. All measures in $\mu \mathrm{m}$ except for nc.

\begin{tabular}{|c|c|c|c|c|c|c|c|c|}
\hline & & $\mathbf{L}$ & B & 12 & h2 & 13 & h3 & nc \\
\hline \multirow{2}{*}{ Torreblanca } & range & $206-500$ & $167-397$ & $71-214$ & $48-127$ & $63-190$ & $56-127$ & $6-10$ \\
\hline & average & 312 & 249 & 129 & 80 & 112 & 80 & 7.72 \\
\hline \multirow{2}{*}{ L'Albufera } & range & $175-603$ & $143-492$ & $63-262$ & $40-127$ & $32-254$ & $40-143$ & $5-9$ \\
\hline & average & 331 & 264 & 137 & 80 & 123 & 77 & 7.48 \\
\hline \multirow{2}{*}{ Peñíscola } & range & $171-540$ & $135-429$ & $60-246$ & $56-135$ & $48-214$ & $40-143$ & $6-9$ \\
\hline & average & 350 & 278 & 146 & 87 & 127 & 85 & 7.68 \\
\hline Total & range & $171-603$ & $135-492$ & $60-262$ & $40-135$ & $32-254$ & $40-143$ & $5-10$ \\
\hline T. aguayoi & average & 331 & 264 & 137 & 82 & 121 & 80 & 7.63 \\
\hline \multirow{2}{*}{ Rüssingen } & range & $183-444$ & $159-333$ & $56-183$ & $48-127$ & $48-183$ & $48-167$ & $4-7$ \\
\hline & average & 183 & 208 & 94 & 84 & 77 & 78 & 5.64 \\
\hline \multirow{2}{*}{ Buñol } & range & $175-333$ & $143-325$ & $56-135$ & $40-127$ & $32-135$ & $48-95$ & $6-8$ \\
\hline & average & 237 & 199 & 83 & 76 & 67 & 66 & 6.44 \\
\hline \multirow{2}{*}{ Fuendetodos } & range & $206-595$ & $167-484$ & $71-262$ & $63-238$ & 48-183 & $56-151$ & $4-6$ \\
\hline & average & 362 & 297 & 148 & 122 & 109 & 96 & 5.20 \\
\hline Total & range & $175-595$ & $143-484$ & $56-262$ & $40-238$ & $32-183$ & $48-167$ & 4-8 \\
\hline R. douvillei & average & 284 & 235 & 108 & 94 & 84 & 80 & 5.76 \\
\hline
\end{tabular}



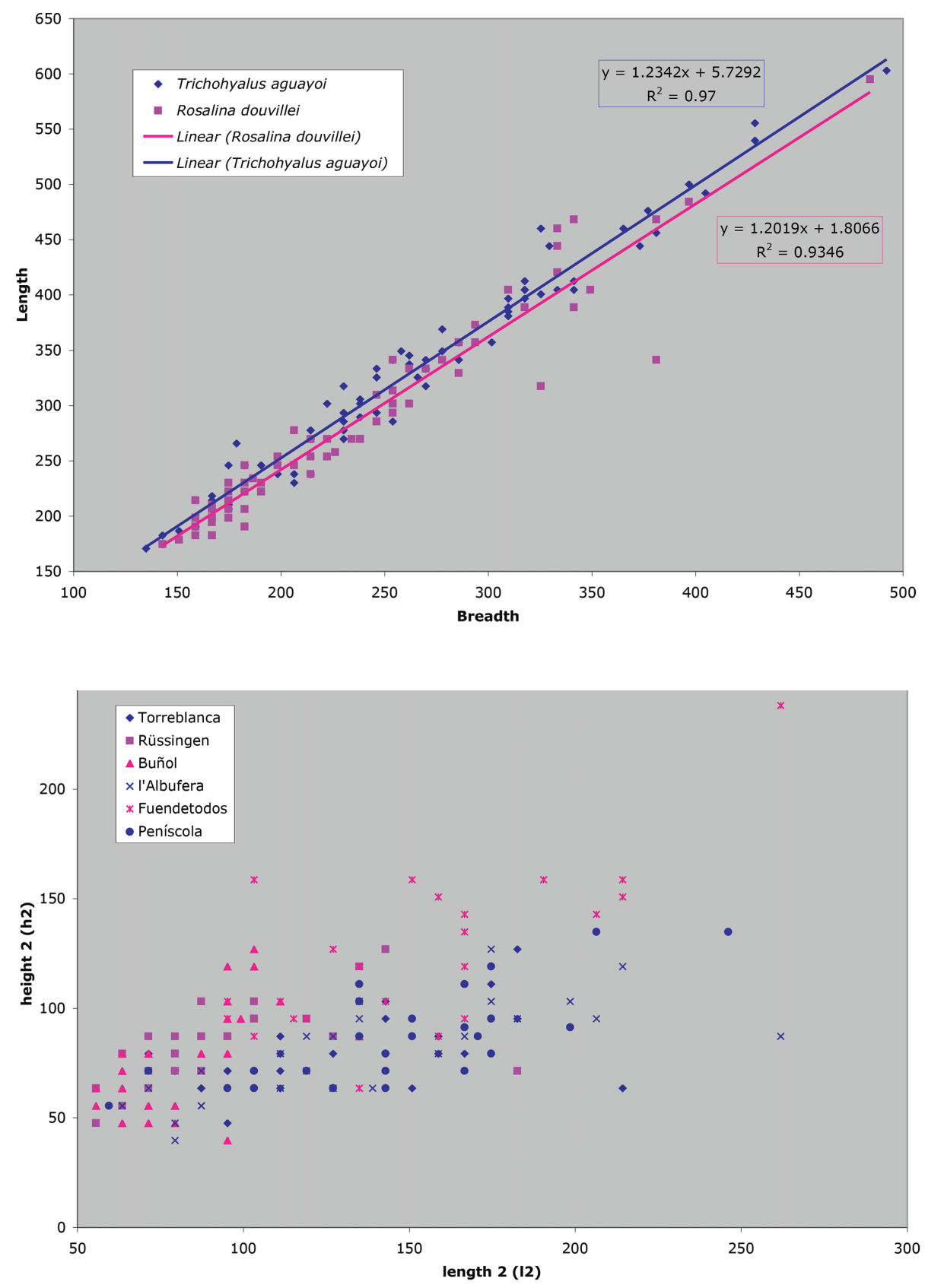

Figure 5. Test length (L) versus breadth (B) of R. douvillei (pink) and T. aguayoi (blue). All measures in $\mu \mathrm{m}$. Regression lines and equations together with the $r^{2}$ coefficient are also shown.
Figure 6. Height $h_{2}$ versus length $l_{2}$ (in $\mu \mathrm{m})$ of the second last chamber of $R$. douvillei (pink) and $T$. aguayoi (blue).
The one-way ANOVA test reveals significant differences between the selected localities for every one of the parameters and ratios considered. Table 2 shows the results of a subsequent post hoc pairwise comparison between the localities employing the Tukey's HSD test (since the normality and equality of variances requirements for an ANOVA test were not always completely met, a KruskalWallis test was carried out in each case to confirm results).

As expected, there are no relevant differences between the T. aguayoi localities, Torreblanca, l'Albufera and Peñíscola, in any of the measured parameters. And, with only one exception (number of chambers in the last whorl), this is also the case between two of the $R$. douvillei sites: Rüssingen and Buñol. There are generally significant differences between both groups (Torreblanca-AlbuferaPeñíscola and Rüssingen-Buñol) in some parameters like length of the second and third last chambers $\left(l_{2}\right.$ and $\left.l_{3}\right)$, number of chambers in the last whorl (nc) and second and third last chambers elongation $\left(1_{2} / h_{2}\right.$ and $\left.l_{3} / h_{3}\right)$, always higher in the T. aguayoi specimens. To a lesser extent this is also the case for the whole test size (Table 2).

The $R$. douvillei specimens from Fuendetodos, however, remarkably differ in some parameters from their cospecific tests and are closer to T. aguayoi. Their tests are significantly larger (both length $\mathrm{L}$ and breadth $\mathrm{B}$ ) than those from Rüssingen or Buñol and comparable to the T. aguayoi tests (Tables 1-2). The same result has been found for the lengths of the second and third last 
chambers $\left(\mathrm{l}_{2}\right.$ and $\left.\mathrm{l}_{3}\right)$ (Tables $\left.2 \mathrm{~B}-2 \mathrm{C}\right)$. The specimens from Fuendetodos are even characterized by the largest heights of the second last chamber $h_{2}$, significantly above the other five localities, which explains the aforementioned higher average values of $\mathrm{h}_{2}$ for $R$. douvillei (Tables 1, 2B; Fig. 6). They also show higher size increase rates from the third to second last chambers $\left(\mathrm{h}_{2} / \mathrm{h}_{3}\right.$ and particularly $1_{2} / 1_{3}$ ) (Table 2F; Fig. 10).

Three of the explored parameters establish a taxonomically coherent separation between $T$. aguayo $i$ and $R$. douvillei among the six localities considered. These are: 1) the number of chambers in the last whorl, always higher in $T$. aguayoi as already seen, and with some differences between the three $R$. douvillei sites (Table 2D); and, 2) the $l_{2} / h_{2}$ and $l_{3} / h_{3}$ ratios, with more elongate chambers in T. aguayoi (Table 2E). The occurrence of a Fuendetodos specimen with an extremely elongate third last chamber (Fig. 8) probably results in a $1_{3} / h_{3}$ mean ratio not significantly different from the $T$. aguayo $i$ from Torreblanca (Table 2E), but the Kruskal-Wallis test confirms the separation between the T. aguayoi and the $R$. douvillei localities also in this case.
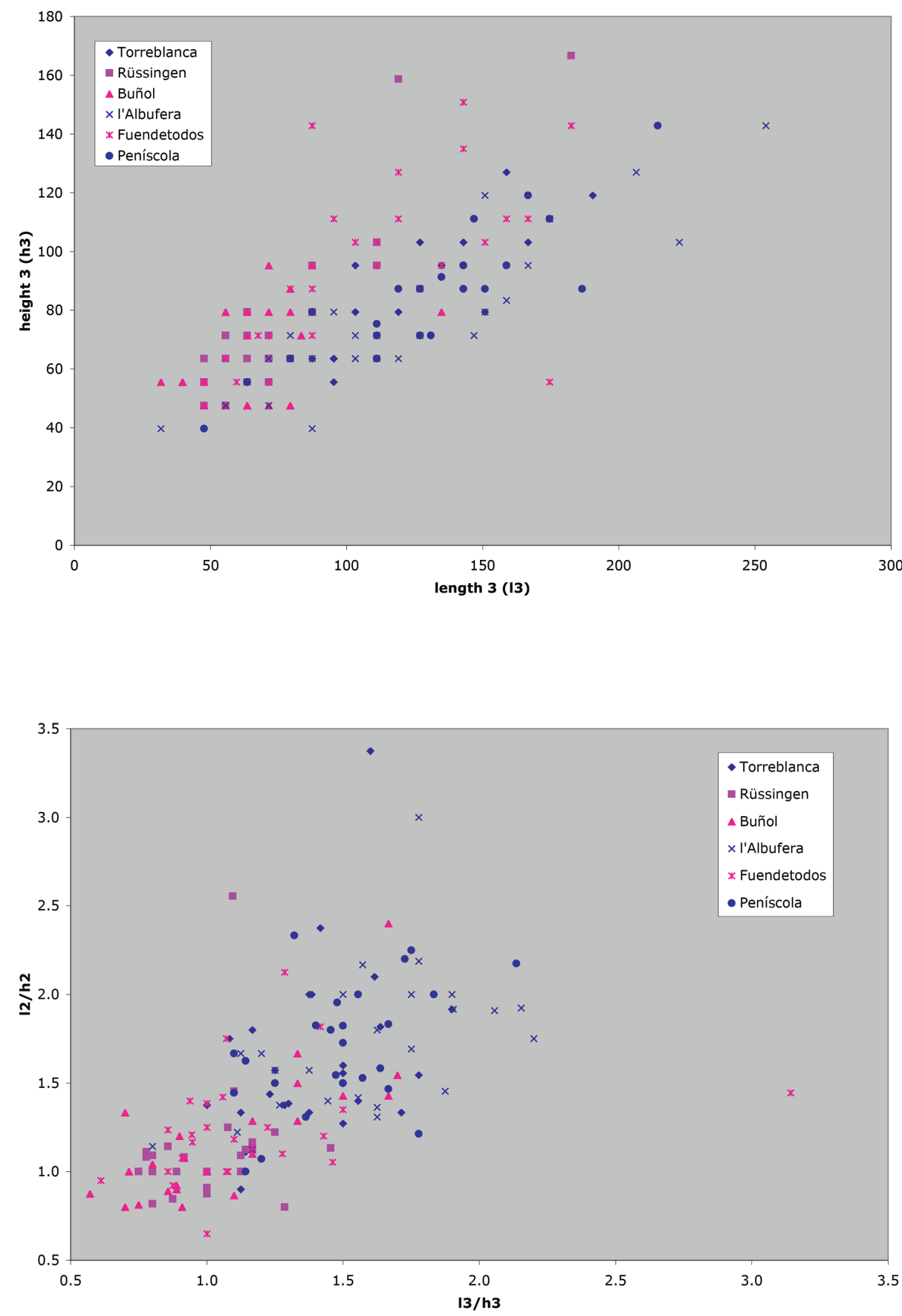

Figure 7. Height $h_{3}$ versus length $l_{3}$ (in $\mu \mathrm{m})$ of the third last chamber of $R$. douvillei (pink) and $T$. aguayoi (blue).

Figure 8. Length:height ratios of the second versus the third last chamber of $R$. douvillei (pink) and T. aguayoi (blue). 

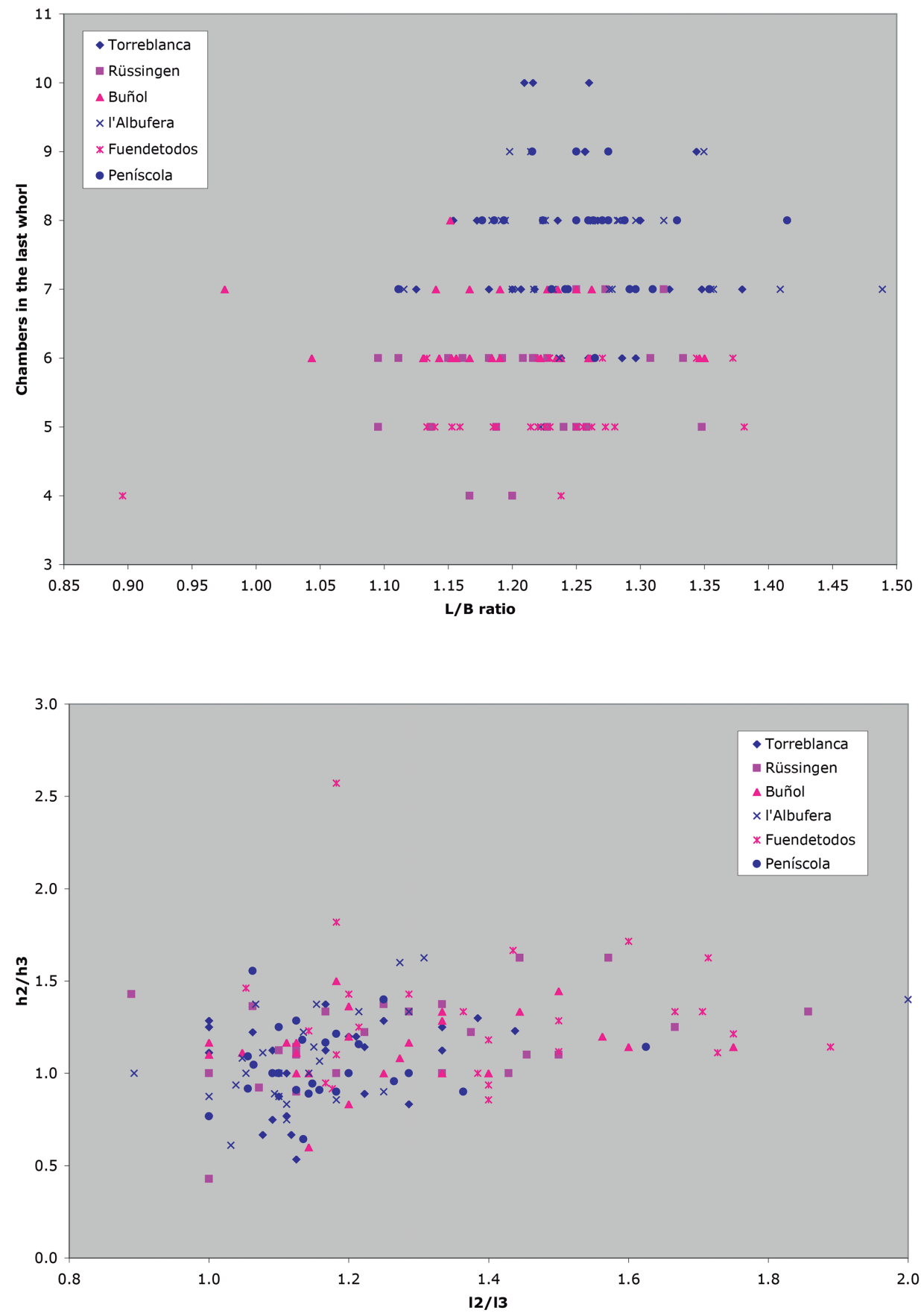

Figure 9. Number of chambers in the last whorl versus index of curvature (L/B ratio) in R. douvillei (pink) and $T$. aguayoi (blue).
Figure 10. Increase rates in height $\left(\mathrm{h}_{2} / \mathrm{h}_{3}\right)$ and length $\left(\mathrm{l}_{2} / \mathrm{l}_{3}\right)$ of the second and third last chambers in $R$. douvillei (pink) and T. aguayoi (blue).

\section{DISCUSSION}

Rosalina douvillei and Trichohyalus aguayoi share many morphological characteristics. The results of the preliminary biometric analysis reveal that many parameters show similar ranges or average values in the two species, such as the height of the third last chamber and the index of test curvature (L/B ratio), or only slight differences, such as in the test breadth, the height of the penultimate chamber or the expansion rate (length and height) between the third and second last chambers. However, both species (at least the two sets of measured individuals) markedly differ in variables like the length and shape of the second and third last chambers and the number of chambers in the last whorl.

One of the main goals of the study by Foresi et al. (2004) was to distinguish between invariant (inherited) and ecophenotypic morphological features in Discorinopsis aguayoi (= Trichohyalus aguayoi) basing on the biometric study of four different brackish water populations (both fossil and recent) of this species in Tuscany (Italy). The measured T. aguayoi specimens in our selected localities (Table 1) do not reach the maximum test sizes of the Bermúdez (1935) syntypes $(800 \mu \mathrm{m})$ but their length (L) 
Table 2. Probabilities resulting from a Tukey's HSD pairwise comparison between localities subsequent to a one-way ANOVA for the parameters and ratios measured in $T$. aguayoi and $R$. douvillei tests. Asterisks show significant differences with $* p$ $<0.05$ and $* * p<0.01$. A) Lower left: test length (L); upper right: test breadth (B). B) Lower left: second last chamber length $\left(1_{2}\right)$; upper right: second last chamber height $\left(\mathrm{h}_{2}\right)$. C) Lower left: third last chamber length $\left(\mathrm{l}_{3}\right)$; upper right: third last chamber height $\left(h_{3}\right)$. D) Lower left: test curvature ratio $(\mathrm{L} / \mathrm{B})$; upper right: number of chambers in the last whorl (nc). E) Lower left: length/height ratio for the second last chamber $\left(\mathrm{l}_{2} / \mathrm{h}_{2}\right)$; upper right: length/height ratio for the third last chamber $\left(1_{3} / h_{3}\right)$. F) Lower left: length increase rate $\left(1_{2} / l_{3}\right)$; upper right: height increase rate $\left(h_{2} / h_{3}\right)$.

\begin{tabular}{llccccc}
\hline $\mathbf{A}$ & Torreblanca & L'Albufera & Peñíscola & Rüssingen & Buñol & Fuendetodos \\
\hline Torreblanca & & 0.976 & 0.677 & 0.267 & 0.105 & 0.130 \\
L'Albufera & 0.965 & & 0.978 & $0.045^{*}$ & $0.012^{*}$ & 0.511 \\
Peñíscola & 0.609 & 0.973 & & $0.004 * *$ & $7.75 \cdot 10^{-4 * *}$ & 0.918 \\
Rüssingen & 0.151 & $0.016^{*}$ & $9 \cdot 10^{-4 * *}$ & & 0.998 & $7.40 \cdot 10^{-5 * *}$ \\
Buñol & $0.024 *$ & $0.001^{* *}$ & $6.03 \cdot 10^{-5 * *}$ & 0.984 & & $2.62 \cdot 10^{-5 * *}$ \\
Fuendetodos & 0.308 & 0.815 & 0.997 & $1.28 \cdot 10^{-4 * *}$ & $2.36 \cdot 10^{-5 * *}$ &
\end{tabular}

\begin{tabular}{|c|c|c|c|c|c|c|}
\hline B & Torreblanca & L'Albufera & Peñíscola & Rüssingen & Buñol & Fuendetodos \\
\hline Torreblanca & & 1 & 0.904 & 0.985 & 0.994 & $2.04 \cdot 10^{-5 * *}$ \\
\hline L'Albufera & 0.986 & & 0.926 & 0.991 & 0.990 & $2.04 \cdot 10^{-5 * *}$ \\
\hline Peñíscola & 0.630 & 0.950 & & 0.999 & 0.608 & $2.72 \cdot 10^{-5 * *}$ \\
\hline Rüssingen & $0.016^{*}$ & $0.001 * *$ & $4.47 \cdot 10^{-5 * *}$ & & 0.831 & $2.12 \cdot 10^{-5 * *}$ \\
\hline Buñol & $3.77 \cdot 10^{-4 * *}$ & $3.47 \cdot 10^{-5 * *}$ & $2.04 \cdot 10^{-5 * *}$ & 0.922 & & $2.03 \cdot 10^{-5 * *}$ \\
\hline Fuendetodos & 0.551 & 0.916 & 1 & $3.35 \cdot 10^{-5 * *}$ & $2.04 \cdot 10^{-5 * *}$ & \\
\hline $\mathrm{C}$ & Torreblanca & L'Albufera & Peñíscola & Rüssingen & Buñol & Fuendetodos \\
\hline Torreblanca & & 0.998 & 0.977 & 1 & 0.380 & 0.169 \\
\hline L'Albufera & 0.908 & & 0.850 & 1 & 0.663 & 0.058 \\
\hline Peñíscola & 0.677 & 0.998 & & 0.931 & 0.080 & 0.583 \\
\hline Rüssingen & $0.018^{*}$ & $3.63 \cdot 10^{-4 * *}$ & $6.14 \cdot 10^{-5 * *}$ & & 0.521 & 0.102 \\
\hline Buñol & $4.73 \cdot 10^{-4 * *}$ & $2.30 \cdot 10^{-5 * *}$ & $2.05 \cdot 10^{-5 * *}$ & 0.929 & & $2.63 \cdot 10^{-4 * *}$ \\
\hline Fuendetodos & 1 & 0.778 & 0.489 & $0.042 *$ & $0.002 * *$ & \\
\hline D & Torreblanca & L'Albufera & Peñíscola & Rüssingen & Buñol & Fuendetodos \\
\hline Torreblanca & & 0.916 & 1 & $2.03 \cdot 10^{-5 * *}$ & $2.13 \cdot 10^{-5 * *}$ & $2.03 \cdot 10^{-5 * *}$ \\
\hline L'Albufera & 0.994 & & 0.960 & $2.03 \cdot 10^{-5 * *}$ & $2.07 \cdot 10^{-4 * *}$ & $2.03 \cdot 10^{-5 * *}$ \\
\hline Peñíscola & 0.997 & 1 & & $2.03 \cdot 10^{-5 * *}$ & $2.29 \cdot 10^{-5 * *}$ & $2.03 \cdot 10^{-5 * *}$ \\
\hline Rüssingen & 0.544 & 0.224 & 0.263 & & $0.010^{*}$ & 0.438 \\
\hline Buñol & 0.133 & $0.030 *$ & $0.039 *$ & 0.9695 & & $2.29 \cdot 10^{-5 * *}$ \\
\hline Fuendetodos & 0.701 & 0.348 & 0.398 & 1 & 0.908 & \\
\hline
\end{tabular}




\begin{tabular}{lllllll}
\hline $\mathbf{E}$ & Torreblanca & L'Albufera & Peñ́scola & Rüssingen & Buñol & Fuendetodos \\
\hline Torreblanca & & 0.390 & 0.927 & $1.29 \cdot 10^{-4 * *}$ & $0.001^{* *}$ & 0.099 \\
L'Albufera & 0.994 & & 0.934 & $2.03 \cdot 10^{-5 * *}$ & $2.04 \cdot 10^{-5 * *}$ & $1.10 \cdot 10^{-4 * *}$ \\
Peñíscola & 0.998 & 1 & & $2.10 \cdot 10^{-5 * *}$ & $3.54 \cdot 10^{-5 * *}$ & $0.005^{* *}$ \\
Rüssingen & $3.76 \cdot 10^{-5 * *}$ & $2.12 \cdot 10^{-5 * *}$ & $2.18 \cdot 10^{-5 * *}$ & & 0.993 & 0.415 \\
Buñol & $1.61 \cdot 10^{-4 * *}$ & $2.98 \cdot 10^{-5 * *}$ & $3.59 \cdot 10^{-5 * *}$ & 0.998 & & 0.782 \\
Fuendetodos & $0.003^{* *}$ & $3.16 \cdot 10^{-4 * *}$ & $4.68 \cdot 10^{-4 * *}$ & 0.869 & 0.982 & \\
& & & & & & \\
\hline F & Torreblanca & L'Albufera & Peñíscola & Rüssingen & Buñol & Fuendetodos \\
\hline Torreblanca & & 0.986 & 1 & 0.397 & 0.759 & $0.002^{* *}$ \\
L'Albufera & 1 & & 0.995 & 0.813 & 0.984 & $0.019 *$ \\
Peñíscola & 1 & 1 & & 0.482 & 0.831 & $0.003 * *$ \\
Rüssingen & 0.319 & 0.270 & 0.375 & & 0.993 & 0.391 \\
Buñol & 0.396 & 0.340 & 0.457 & 1 & & 0.130 \\
Fuendetodos & $9.26 \cdot 10^{-5 * *}$ & $6.62 \cdot 10^{-5 * *}$ & $1.35 \cdot 10^{-4 * *}$ & 0.119 & 0.086 & \\
\hline
\end{tabular}

Table 2. (Continued)

variation $(171-603 \mu \mathrm{m})$ is totally within the range recorded by Arnold (1954) in laboratory specimens (60-750 $\mu \mathrm{m}$, although these included also juvenile specimens). On the other hand, they encompass the limits observed by Tufesco (1969) in the Golovita lagoon in Romania $(271-443 \mu \mathrm{m})$ and by Foresi et al. (2004) in their Italian localities (180$560 \mu \mathrm{m})$. The average length $(331 \mu \mathrm{m})$ is almost identical to the one obtained by Foresi et al. (2004) in the locality of Montecatini $(330 \mu \mathrm{m})$. The test breadth (B) range (135$492 \mu \mathrm{m})$ is also wider than the one observed in Golovita (200-343 $\mu \mathrm{m})$ and somewhat lower, although with a strong overlap, than the variation $(160-520 \mu \mathrm{m})$ recorded by Foresi et al. (2004). According to their study, size depends either on individual growth or on environmental conditions (salinity and others), as it has been established in foraminiferal ecological surveys (Boltovskoy \& Wright, 1976). The size differences observed in general between T. aguayoi and $R$. douvillei, or between the $R$. douvillei specimens from Fuendetodos and those from Rüssingen or Buñol, might therefore be attributed to any of these two factors.

The curvature index $(\mathrm{L} / \mathrm{B})$ variation of the selected $T$. aguayoi specimens (1.11-1.49) is nearly identical to the one recorded by Tufesco (1969) in the Golovita lagoon (1.1-1.5) and reflects a more or less elongate test outline in this species. The $R$. douvillei specimens show a somewhat more circular outline (L/B range: 0.90-1.38) but without strong significant differences with the T. aguayoi localities (Table 2D). Foresi et al. (2004) report a high degree of variability in $T$. aguayoi and attribute the variation in this character to environmental conditions.
Chamber shape is less obviously related to external influences. The length:height ratios measured on the second and third last chambers in our T. aguayoi tests again yield mean values $\left(1_{2} / h_{2}=1.65-1.71 ; 1_{3} / h_{3}=1.40-1.58\right)$ well within the range observed in the Italian specimens $\left(1_{2} / \mathrm{h}_{2}\right.$ $=1.45-1.93 ; 1_{3} / h_{3}=1.32-1.80$ sensu Foresi et al., 2004), all of which still remain above those measured in the $R$. douvillei specimens (range of average $\mathrm{l}_{2} / \mathrm{h}_{2}=1.12-1.24 ; 1_{3}$ / $\left.\mathrm{h}_{3}=1-1.17\right)$. So, $T$. aguayoi shows systematically narrower and more elongate second and third last chambers than $R$. douvillei. This pattern is persistent among the six studied localities, even taking into account the considerably higher second last chamber (high $\mathrm{h}_{2}$ ) of the $R$. douvillei specimens from Fuendetodos. This is consistent with the attribution of the variation in this character to both environmental influences and heredity by Foresi et al. (2004).

As mentioned above, chamber shape cannot be considered as totally independent from the number of chambers in the last whorl. More chambers imply less space and consequently narrower and more elongate chambers. The T. aguayoi specimens show a range of 5-10, mainly 7-8 chambers in the outer whorl, nearly identical to that observed by Tufesco (1969) and by Foresi et al. (2004), who consider the maximum value as an invariant taxonomic character. This sets a marked difference, which is also constant in the studied six localities, with the specimens of $R$. douvillei, characterised by 4-8 (mainly 5-6) chambers in the last whorl. It is interesting to note that the Fuendetodos specimens show the lowest number of chambers (4-6), which is consistent with their higher second last chamber (Tables 1, 2B) and also with their larger chamber size increase $\left(l_{2} / l_{3}\right.$ and $\left.h_{2} / h_{3}\right)$. 
Finally, the complexity of the umbilical calcareous filling is attributed by Foresi et al. (2004) to the availability of $\mathrm{CaCO}_{3}$. This structure is always present in T. aguayoi but in $R$. douvillei it is much reduced or absent in microspheric forms. Its function is unclear. Unfortunately, the number of macrospheric forms among the selected tests was too low to establish confident biometric comparisons. The relative scarcity of the macrospheric form was already recorded by Márquez \& Usera (1988) in Buñol.

The absence of significant differences between the T. aguayoi specimens of the studied localities is not surprising. The three localities are closely related both geographically and ecologically. All correspond to Mediterranean coastal lagoons located in the Valencian Community and therefore they are/were presumably subject to very similar environmental conditions. Moreover, they are either Holocene or Recent in age, so there are no significant chronological gaps between them. In contrast, the $R$. douvillei sites are from different geographical areas that range from the Oligocene/Miocene to the middle/ upper Miocene. In addition, they correspond to different environments from marginal marine-influenced areas (Rüssingen) to continental lakes (Buñol). Nevertheless, the specimens from Rüssingen and Buñol are relatively similar to each other (Table 2) and markedly different from the Fuendetodos tests. These differences, if confirmed by further research, might be explained by local environmental characteristics in a restricted area (the nature of the Fuendentodos palaeoenvironment is problematic, see Anadón et al., 1997) or by the chronological interval separating Fuendetodos from the other sites (at least 4 Ma from Buñol and about 11 Ma from Rüssingen), but probably additional factors (e.g., evolutionary change) cannot be ruled out.

The morphological similarities between T. aguayoi and $R$. douvillei suggest a similar mode of life. Trichohyalus aguayoi is a euryhaline species living in shallow warmtemperate brackish waters. It has an epiphytic/epifaunal or shallow infaunal life style and thrives in fine grain sediments rich in organic matter and macrophyte remains (Tufesco, 1969). Rosalina douvillei has also been always found in brackish waters deposits (e.g., Le Calvez, 1970), either in marginal marine areas or in saline lakes. Little is known however about its life style. Like T. aguayoi, its low trochospiral test is coherent with an epiphytic or epifaunal life, with its aperture and its mainly imperforate umbilical side turned towards the substrate and its perforate spiral side exposed to the open water (Hottinger, 2000). Extant representatives of this genus, such as Rosalina globularis d'Orbigny, 1826, are indeed epiphytic, although they are strictly marine species (e.g., Colom, 1974; Martins \& Dragao-Gomes, 2004).

As stated above, $R$. douvillei has a long stratigraphic range that lasts from the upper Eocene up to the Miocene. The last known occurrence of this species is dated as middle/upper Miocene (Anadón et al., 1997) whereas the oldest known T. aguayoi are Messinian (upper Miocene) in age (Foresi et al., 2004), which results in a cronostratigraphic separation of roughly 4-6 Ma between the two species. Despite their many similar morphological traits, including a calcareous umbilical filling, they are classified in different non-closely related taxonomic groups and the generic status of T. aguayoi in particular is problematic. Its classification in Discorinopsis (Scott et al., 1990, 1991) would still place this species in the agglutinated order Textulariida (Hayward et al., 2017). On the other hand, according to Le Calvez (1970), R. douvillei represents an intermediate evolutionary stage between the Eocene Rosalina quadrata Terquem, 1882 and the Miocene to Recent $R$. globularis. As far as it is known to us, no genetic foraminiferal study including T. aguayoi and any extant representative of Rosalina (e.g., $R$. globularis) has been carried out yet.

Thus, the question as to whether the observed similarities between T. aguayoi and $R$. douvillei constitute another case of morphological convergence, as it has been repeatedly the case in the evolution of foraminifera (Tappan \& Loeblich, 1988), or they are the consequence of a close taxonomic proximity between the two species, cannot be elucidated here. A preliminary comparison between the upper Miocene (Messinian) specimens of T. aguayoi from Rosignano Marittimo studied by Foresi et al. (2004) and their chronostratigraphically closest $R$. douvillei tests from the middle/upper Miocene site of Fuendetodos still shows that the T. aguayoi tests are considerably larger, they have more chambers in the last whorl (6-10) and their second and third last chambers are clearly more elongate, which seems to point to different lineages with morphological affinities derived from their similar habitat. Further research to improve knowledge about the stratigraphic range of the two species and more complete biometric comparisons (including more specimens and additional biometric parameters) between their Miocene representatives may help to clarify their eventual relationship.

\section{CONCLUSIONS}

The biometric analysis of randomly selected tests from six Neogene and Quaternary localities reveals two taxonomically and morphologically coherent groups: the three T. aguayoi localities, Torreblanca, l'Albufera, and Peñíscola, and two of the $R$. douvillei sites, Rüssingen and Buñol. Both groups share some morphological characteristics such as the curvature ratio, the heights of the second and third last chambers and the chamber size increase and differ in others like size and chamber length. 
Due probably to several factors (e.g., environmental conditions in a restricted basin, evolutionary change), the $R$. douvillei tests in Fuendetodos display peculiar characteristics: they are as large as T. aguayoi and show the highest second last chambers and the highest chamber size increase rates. Apart from this, T. aguayoi is always characterised by more chambers in the last whorl and more elongate second and third last chambers than $R$. douvillei, which confirms that chamber shape and the number of chambers in the last whorl are at least in part related to heredity factors. Further research is required to clarify if the affinities between the two species are due to phylogenetic proximity or, more probably, to morphological convergence between two non-related taxa, derived from a similar habitat.

\section{ACKNOWLEDGMENTS}

We gratefully acknowledge the helpful comments and suggestions of Matías Reolid and an anonymous reviewer, which have greatly improved an earlier version of the manuscript. This work has benefited from a research grant by the CAISEP (Comisión de Ayudas a la Investigación de la Sociedad Española de Paleontología) awarded to the first author AGB.

\section{REFERENCES}

Albani, A.D. 1968. Recent Foraminiferida from Port Hacking, New South Wales. Contributions from Cushman Foundation for Foraminiferal Research, 19, 85-119.

Albani, A.D., Favero, V. \& Serandrei Barbero, R. 1991. The distribution and ecological significance of recent foraminifera in the Lagoon South of Venice (Italy). Revista Española de Micropaleontología, 23, 29-45.

Anadón, P. 1989. Los lagos salinos interiores (atalásicos) con faunas de afinidad marina del Cenozoico de la Península Ibérica. Acta Geológica Hispánica, 24, 83-102.

Anadón, P. 1992. Composition of inland waters with marinelike faunas and inferences for a Miocene lake in Spain. Palaeogeography, Palaeoclimatology, Palaeoecology, 99, 1-8; doi: 10.1016/0031-0182(92)90002-M.

Anadón, P., Pérez, A., Rodríguez Lázaro, J., Usera, J., GarcíaForner, A., Utrilla, R. \& Talbot, M.R. 1997. Contrastes en el análisis paleoambiental de los depósitos con fauna de afinidad marina del Mioceno de la Cuenca del Ebro. In: Avances en el Conocimiento del Terciario Ibérico (eds. Calvo, J.P. \& Morales. J.), 21-24.

Andreieff, P., Anglada, R., Aubert, J., Blondeau, A., Bourdon, M., Caralp, M., Le Calvez, Y., Lorenz, C., Magne, J., Poignant, A. \& Pujol, C. 1974. Étude biostratigraphique des gisements d'Escornebéou (Aquitaine méridionale,
France), Foraminifères. Documents du Laboratoire de Géologie de la Faculté de Sciences de Lyon, 59, 31-55.

Arco, Y., Usera, J., Brito, J. \& Gabarda, J. 1991. Dinámica poblacional biológica y tafonómica de los foraminíferos de la marjal de Torreblanca (Castellón). VII Jornadas de Paleontología de la Sociedad Española de Paleontología. Oviedo, p. 9.

Arnold, Z.M. 1954. Discorinopsis aguayoi (Bermúdez) and Discorinopsis vadescens Cushman and Brönnimann: a study of variation in cultures of living foraminifera. Contributions from Cushman Foundation for Foraminiferal Research, 5, 4-13.

Barbin, V. \& Keller-Grünig, A. 1991. Benthic foraminiferal assemblages from the Brendola section (Priabonian stage stratotype area, northern Italy): Distribution, palaeoenvironment and palaeoecology. Marine Micropaleontology, 17, 237-254.

Batjes, D.A.J. 1958. Foraminifera of the Oligocene of Belgium. Institut Royal Des Sciences Naturelles De Belgique, 143, 1-188.

Bermúdez, P.J. 1935. Foraminíferos de la Costa norte de Cuba. Memorias de la Sociedad Cubana de la Historia Natural "Felipe Poey", 9, 129-224.

Bernabé, M.J., Schäfer, P., Sánchez, E.J. \& Usera, J. 1991. Dinámica poblacional tafonómica de los foraminíferos del tránsito Oligoceno-Mioceno de Rüssingen (Alemania). VII Jornadas de Paleontología de la Sociedad Española de Paleontología. Oviedo, p. 11.

Blázquez, A.M. 2005. Evolución Cuaternaria de l'Albufera d'Elx: Paleoambientes y Foraminiferos Fósiles. Memorias del MUPE, Alacant, Elx.

Blázquez, A.M. \& Ferrer, C. 2003. L'Albufereta d'Alacant: foraminíferos y evolución paleoambiental. Cuaternario y Geomorfología, 18, 55-72.

Blázquez, A.M. \& Usera, J. 2004. Ensayo de síntesis sobre la evolución cuaternaria de l'Albufera d'Elx (Alicante). Geotemas, 7, 129-132.

Blázquez, A.M. \& Usera, J. 2005. Variaciones de la línea de costa en l'Albufera d'Elx (Alicante) durante el Cuaternario reciente. In: Geomorfologia Litoral i Quaternari, Homenatge al Professor Vicenç M. Rosselló $i$ Verger (eds. Sanjaume, E. \& Mateu, J.F.). Universitat de València Estudi General, 59-72.

Boltovskoy, E. \& Hincapié de Martínez, S. 1983. Foraminíferos del Manglar de Tesca, Cartagena, Colombia. Revista Española de Micropaleontología, 15, 205-220.

Boltovskoy, E. \& Vidarte, L.M. 1977. Foraminíferos de la zona de manglar de Guayaquil (Ecuador). Revista del Museo Argentino de Ciencias Naturales "Bernardino Rivadavia", 5, 31-40.

Boltovskoy, E. \& Wright, R. 1976. Recent Foraminifera. Dr. W. Junk. The Hague.

Brady, H.B. 1881. Notes on some of the reticularian Rhizopoda of the "Challenger" Expedition; Part III. Quarterly Journal of the Microscopical Society, 21, 31-71.

Burgess, M.V. \& Schnitker, D. 1990. Morphometry of Bulimina aculeata Orbigny and Bulimina marginata Orbigny. Journal of Foraminiferal Research, 20, 37-49. 
Burki, F., Shalchian-Tabrizi, K., Minge, M., Skaeveland, A., Nicolaev, S.I., Jakobsen, K.S. \& Pawlowsky, J. 2007. Phylogenomics reshuffles the eukaryotic supergroups. In G. Butler. PLoS ONE 2, e790; doi: 10.1371/journal. pone.0000790.

Buzas, M.A. 1966. The discrimination of morphological groups of Elphidium (Foraminifer) in Long Island Sound through canonical analysis and invariant characters. Journal of Paleontology, 40, 585-594.

Calzada, S. 1970. Una turbera parálica postwürmiense en Vilanova y La Geltrú. (Barcelona). Acta Geológica Hispánica, 5, 48-50.

Cann, J.H. \& De Dekker, P. 1981. Fossil Quaternary and living foraminifera from athalassic (non-marine) saline lakes, southern Australia. Journal of Paleontology, 55, 660-670.

Caralp, M.H. 1989. Size and morphology of the benthic foraminifer Melonis barleeanum, relationships with marine organic matter. Journal of Foraminiferal Research, 19, 235-245.

Carmona, P., Ruiz-Pérez, J.M., Blázquez, A.M., LópezBelzunce, M., Riera, S. \& Orengo, H. 2016. Environmental evolution and mid-late Holocene climate events in the Valencia lagoon (Mediterranean coast of Spain). The Holocene, 26, 1750-1765; doi: 10.1177/0959683616645940.

Cavalier-Smith, T. 2002. The phagotrophic origin of eukaryotes and phylogenetic classification of Protozoa. International Journal of Systematic and Evolutionary Microbiology, 52, 297-354; doi: 10.1099/00207713-522-297.

Cavalier-Smith, T. 2010. Kingdoms Protozoa and Chromista and the eozoan root of the eukaryotic tree. Biology Letters, 6, 342-354; doi: 10.1098/rsbl.2009.0948.

Cearreta, A., Benito, X., Ibáñez, C., Trobajo, R. \& Giosan, L. 2016. Holocene palaeoenvironmental evolution of the Ebro Delta (Western Mediterranean Sea): Evidence for an early construction based on the benthic foraminiferal record. The Holocene, 26, 1438-1456; doi: 10.1177/0959683616640048.

Collins, A.C. 1958. Foraminifera. Science Report Great Barrier Reef Expedition. 6, 335-437.

Collins, L. 1989. Relationship of environmental gradients to morphologic variation within Bulimina aculeata and Bulimina marginata, Gulf of Maine area. Journal of Foraminiferal Research, 19, 222-234.

Colom, G. 1974. Foraminíferos ibéricos. Introducción al estudio de las especies bentonicas recientes. Investigación Pesquera, 38, 1-245.

Corliss, B.H. 1979. Size variation in the deep-sea benthonic foraminifer Globocassidulina subglobosa (Brady) in the Southeast Indian Ocean. Journal of Foraminiferal Research, 9, 50-60.

Cushman, J.A. 1928. Foraminifères du Stampien du Bassin de Paris. Bulletin de la Société Science de Seine-et-Oise, 9, 47-57.

Daams, R. \& Freudenthal, M. 1981. Aragonian: the Stage concept versus Neogene Mammal zones. Scripta Geológica, 62, 1-17.
Delage, Y. \& Herouard, E. 1896. Traité de Zoologie Concrète. Libraire C. Reinwald. Schleicher Frères, Éditeurs, Paris.

d'Orbigny, A. 1826. Tableau méthodique de la classe des Céphalopodes. Annales des Sciences Naturelles, Paris, 7, 245-314.

Dupré, M., Fumanal, M.P., Sanjaume, E., Santisteban, C., Usera, J. \& Viñals, M.J. 1988. Quaternary evolution of the Pego coastal lagoon (Southern Valencia, Spain). Palaeogeography, Palaeoclimatology, Palaeoecology, 8, 291-299; doi: 10.1177/0959683616645940.

Ehrenberg, C.G. 1838. Die Infusionsthierchen als Vollkommene Organismen. Verlag von Leopold Voss, Leipzig.

Ferrer, C., Blázquez, A.M., Esquembre, M.A. \& Ortega, J.R. 2005. Reconstrucción paleoambiental de l'Albufereta d'Alacant durante el periodo ibero-romano (500 a.C.-300 d.C.). In: Geomorfologia Litoral i Quaternari, Homenatge al Professor Vicenç M. Rosselló i Verger (eds. Sanjaume, E. \& Mateu, J.F.). Universitat de València Estudi General, 137-150.

Foresi, L.M., Focardi, S. \& Zampi, M. 2004. Test morphology and organic layer of Discorinopsis aguayoi (Bermúdez) relationships with environmental conditions. Revista Española de Micropaleontología, 36, 323-347.

García-Forner, A. 1997. Foraminíferos Cuaternarios de las Marjales de Oliva-Pego y Xàbia (Valencia-Alicante). Paleoecología y Evolución. Ph.D. Thesis, Universitat de València Estudi General (unpublished).

García-Forner, A., Domingo, C., Faura, M. \& Usera, J. 1993. Posibles estrategias poblacionales de algunas especies de foraminíferos bentónicos en las cuencas atalásicas cuaternarias de la Comunidad Valenciana. In: Estudios sobre Cuaternario (eds. Fumanal, M.P. \& Bernabeu, J.), València, 75-82.

Gary, A.C., Healy-Williams, N. \& Ehrlich, R. 1989. Watermass relationships and morphologic variability in the benthic foraminifer Bolivina albatrossi Cushman, northern Gulf of México. Journal of Foraminiferal Research, 19, 210-221.

Gebhardt, H. 2003. Palaeobiogeography of Late Oligocene to Early Miocene Central European Ostracoda and Foraminifera: progressive isolation of the Mainz Basin, northern Upper Rhine Graben and Hanau Basin/Wetterau. Palaeogeography, Palaeoclimatology, Palaeoecology, 201, 343-354; doi: 10.1016/S0031-0182(03)00619-9.

Guillem, J. 2007. Tafonomía, Taxonomía y Ecología de los Foraminiferos de la Albufera de Torreblanca. Ph.D. Thesis, Universitat de València Estudi General (unpublished).

Hallock, P., Röttger, R. \& Wetmore, K. 1991. Hypotheses on form and function in foraminifera. In: Biology of Foraminifera (eds. Lee, J.J. \& Anderson, O.R.). Academic Press, London, 41-72.

Hammer, Ø. \& Harper, D. 2006. Paleontological Data Analysis. Blackwell Publishing, Malden.

Haynes, J.R. 1981. Foraminifera. MacMillan Publishers, London.

Hayward, B.W., Cedhagen, T., Kaminski, M. \& Gross, O. 2017. World Foraminifera Database. http://www. marinespecies.org/foraminifera. 
Hayward, B.W., Holzmann, M., Grenfell, H.R., Pawlowski, J. \& Triggs, C.M. 2004. Morphological distinction of molecular types in Ammonia - towards a taxonomic revisión of the world's most commonly misidentified foraminifera. Marine Micropaleontology, 50, 237-271.

Hottinger, L. 1978. Comparative Anatomy of Elementary Shell Structures in Selected Larger Foraminifera. In: Foraminifera (eds. Hedley, R.H. \& Adams, C.G.). Academic Press, London, 3, 203-266.

Hottinger, L. 2000. Functional morphology of benthic foraminiferal shells, envelopes of cells beyond measure. Micropaleontology, suppl. 1, 57-86.

Javaux, E.J. \& Scott, D.B. 2003. Illustration of modern benthic foraminifera from Bermuda and remarks on distribution in other subtropical/tropical areas. Palaeontologia Electronica, 6, http://palaeo-electronica. org/2003 1/benthic/issue1_03.htm.

Kadolsky, D. 1988. Stratigraphie und Molluskenfaunen von „Landschneckenkalk“ und „Cerithienschichten“ im Mainzer Becken (Oberoligozän bis Untermiozän?). Stratigraphische, paläogeographische und paläoökologische Ergebnisse. Geologisches Jahrbuch A, 110, 69-133.

Le Calvez, Y. 1966. Contribution à l'étude des Foraminifères de l'Oligocène inférieur (Sannoisien) dans le Bassin de Paris. Eclogae Geologicae Helveticae, 59, 401-419.

Le Calvez, Y. 1970. Contribution à l'Étude des Foraminifères Paléogènes du Bassin de Paris. Cahiers de Paléontologie, CNRS, Paris.

Lehmann, G., Röttger, R. \& Hohenegger, J. 2006. Life cycle variation including trimorphism in the foraminifer Trochammina inflata from north European salt marshes. Journal of Foraminiferal Research, 36, 279-290.

Lévy, A. 1982. Sur la survie de certains Foraminifères dans les eaux continentales et sur ses conséquences. Mémoires de la Société Géologique de France, 144, 161-171.

Loeblich, A.R. \& Tappan, H. 1953. Studies of Arctic foraminifera. Smithsonian Miscellaneous Collections, 121, 1-150.

López Buendía, Á.M. 1995. Evolución Cuaternaria de las Cuencas Palustres Litorales de la Depresión ValenciaCastellón. Ph.D. Thesis, Universidad de Zaragoza.

Loubere, P., Banonis, G. \& Jakiel, R. 1988. Globocassidulina subglobosa (Brady); environmental control of species abundance and specimen test size. Journal of Foraminiferal Research, 18, 6-15.

Made, J. van der, Belinchón, M. \& Montoya, P. 1998. Suoidea (Mammalia) from the Lower Miocene locality of Buñol, Valencia, Spain. Geobios, 31, 99-112; doi: 10.1016/S00166995(98)80100-9.

Malmgren, B.A. 1984. Analysis of the environmental influence on the morphology of Ammonia beccarii (Linné) in southern european salinas. Geobios, 17, 737-746.

Márquez, L. \& Usera, J. 1984. Una fauna de foraminíferos en el Mioceno continental de la localidad de Buñol (Provincia de Valencia). Estudios Geológicos, 40, 225-230.

Márquez, L. \& Usera, J. 1988. Neogene Foraminifera from the mammalian rich layers of the lacustrine basin of Buñol (Valencia, Spain). Revue de Paléobiologie. Vol. Esp. 2, 575-579.
Martins, M.V.A. \& Dragao-Gomes, V.C.R. 2004. Foraminiferos da Margem Continental NW Ibérica. Figueiredo Gomes, C.S. (ed.).

Mateu, G. \& Viñals, M.J. 1990. Biofacies margino-littorales de la Méditerranée occidentale (Baleares, Valencia, Alicante et Murcia) Espagne. XXXe Congrés C.I.E.S.M., Perpignan, 1-10.

Murray, J.W. 1991. Ecology and Palaeoecology of Benthic Foraminifera. New York: Longman Scientific and Technical.

Odrzywolska-Bienkowa, E. \& Pozaryska, K. 1984. Priabonian foraminifers of the polish lowlands. Acta Palaeontologica Polonica, 29, 107-156.

Pawlowski, J., Holzmann, M. \& Tyszka, J. 2013. New supraordinal classification of Foraminifera: Molecules meet morphology. Marine Micropaleontology, 100, 1-10; doi: 10.1016/j.marmicro.2013.04.002.

Pérez, A. 1989. Estratigrafía y Sedimentología del Terciario del Borde Meridional de la Depresión del Ebro (Sector Riojano-Aragonés) y Cubetas de Muniesa y Montalbán. Ph.D. Thesis. Universidad de Zaragoza.

Raup, D.M. \& Stanley, S.M. 1971. Principles of Paleontology. Freeman and Company, San Francisco.

Reiss, Z. 1963. Reclassification of perforate foraminifera. Bulletin of the Geological Survey of Israel, 35, 1-111.

Resig, S.M. 1974. Recent foraminifera from a landlocked Hawaiian lake. Journal of Foraminiferal Research, 4, 69-76.

Riba, O. 1989. Unidades tectosedimentarias y secuencias deposicionales. Revista de la Sociedad Geológica de España, 2, 189-198.

Robles, F., Collado, M.A. \& Borredá, V. 1985. Variaciones de la fauna de moluscos de la Albufera de Valencia: implicaciones paleogeográficas. In: Geomorfología Litoral y Cuaternario. Homenaje a Juan Cuerda. Universidad de Valencia, Eidgenössische Technische Hochschule. Zurich. Universitat de Palma de Mallorca, 123-133.

Rothausen, K. \& Sonne, V. 1988. Das Tertiär des Mainzer Beckens. Geologisches Jahrbuch A, 110, 5-16.

Saidova, K.M. 1981. O Sovremennom Sostoyanii Sistemy Nadvidovykh Kaynozoyskikh Bentosnikh Foraminifer (On an up-to-date System of Supraspecific Taxonomy of Cenozoic Benthonic Foraminifera). Institut Okeanologii P.P.Shirshova, Akademiya Nauk, SSSR, Moscow.

Scott, G.H. 1974. Biometry of the Foraminiferal Shell. In: Foraminifera (eds. Hedley, R.H. \& Adams, C.G.). Academic Press, London, 1, 55-151.

Scott, D.B., Piper, D.J.W. \& Panagos, A.G. 1979. Recent salt marsh and intertidal mudflat foraminifera from the western coast of Greece. Rivista Italiana di Paleontologia e Stratigrafia, 85, 243-266.

Scott, D.B., Schnack, E.J., Ferrero, L., Espinosa, M. \& Barbosa, C.F. 1990. Recent marsh foraminifera from the east coast of South America: comparison to the northern hemisphere. In: Paleoecology, Biostratigraphy, Paleoceanography and Taxonomy of Agglutinated Foraminifera (eds. Hemleben, C., Kaminski, M.A., Kuhnt, W. \& Scott, D.B.). NATO ASI Series C, 327, 717-737. 
Scott, D.B., Suter, J.R. \& Kosters, E.C. 1991. Marsh foraminifera and arcellaceans of the lower Mississippi Delta: controls on spatial distributions. Micropaleontology, 37, 373-392.

Setiawan, J.R. 1983. Foraminifera of the type Priabonian. Utrecht Micropaleontological Bulletins, 29, 1-173.

Showers, W.J. 1980. Biometry of the foraminifera Rosalina globularis (d'Orbigny) in Antarctic environments. Journal of Foraminiferal Research, 10, 61-74.

Tappan, H. \& Loeblich, A.R.Jr. 1988. Foraminiferal evolution, diversification, and extinction. Journal of Paleontology, 62, 695-714.

Terquem, O. 1882. Les Foraminifères de l'Éocène des environs de Paris. Mémoires de la Société Géologique de France, ser. 3, 2, 1-193.

Tufesco, M. 1969. Sur la présence de Trichohyalus aguayoi (Bermúdez) dans la mer Noire. Revue de Micropaléontologie, 12, 46-52.

Tufescu, M. 1973. Les associations de foraminifères du nord-ouest de la Mer Noire. Revista Española de Micropaleontología, 5, 15-32.

Usera, J. 2003. Guillermo Colom y los estudios de foraminíferos de cuencas parálicas y atalásicas. In: Guillem Colom Casasnovas, Naturalista i Geòleg: Pioner i Mestre de la Micropaleontologia Espanyola (ed. Mateu, G.). Universitat de les Illes Balears, Palma, 33-55.

Usera, J., Liebau, A. \& García-Forner, A. 1989. Presencia de Trichohyalus aguayoi (Bermúdez 1985) (Foraminiférida) en el Delta del Ebro (Tarragona). IX Bienal de la Real Sociedad Española de Historia Natural, Sevilla, 277.

Usera, J., Faura, M. \& Arco, Y. 1990a. Foraminíferos cuaternarios de las fases de colmatación de la Albufera de Valencia. V Jornadas de Paleontología Sociedad Española de Paleontología, Granada, 61.

Usera, J., Robles, F., Martínez-López, F. \& Arco, Y. 1990b. Fauna actual de gasterópodos y foraminíferos de la marjal de Torreblanca (Castellón). VIII Congreso nacional de Malacología, Valencia, 101.

Usera, J., Anadón, P., Pérez, A. \& García-Forner, A. 1991a. Los foraminíferos de los depósitos lacustres miocenos de la cubeta de Azuara (Margen meridional de la Depresión del Ebro, Zaragoza). VII Jornadas de Paleontología de la Sociedad Paleontología, Oviedo, 24-26.

Usera, J., Sánchez, E.J. \& Faura, M. 1991b. El género Aubignyna Margerel, 1970 (Foraminiferida) en el Mioceno, Plioceno, Cuatenario y Actual de algunas localidades del Mediterráneo occidental. Revista Española de Paleontología, $\mathrm{N}^{\circ}$. Extra, 163-171.

Usera, J., López Buendía, Á.M. \& Alberola, C. 1996. Foraminíferos cuaternarios de la turbera de Benicasim
(Castellón). XII Bienal de la Real Sociedad Española de Historia Natural, Madrid, 200.

Usera, J., Blázquez, A.M. \& Alberola, C. 2001. Foraminíferos y paleoambientes cuaternarios en la Cuenca del Bajo Segura (Alicante). In: Los Fósiles y la Paleogeografía. Publicaciones del Seminario de Paleontología de Zaragoza, 5, 494-502.

Usera, J., Alberola, C. \& Blázquez, A.M. 2003. Foraminíferos, tecamébidos y paleoambiente en el Holoceno de la Antigua laguna costera de Peñíscola (Castellón). XI Reunión de Cuaternario (ed. Flor, G.). Oviedo, 301-306.

Usera, J., Alberola, C. \& Brito, J. 2006a. Foraminíferos cuaternarios de la Albufera de Valencia: Sondeo "El Palmar". XXII Jornadas de Paleontología de la Sociedad Española de Paleontología, León, 193-194.

Usera, J., Blázquez, A.M., Guillem, J. \& Alberola, C. 2006 b. Evolución holocena de la marjal de Peñíscola (Castellón, España) deducida del estudio de sus foraminíferos fósiles. Revista Española de Micropaleontología, 38, 381-393.

Usera, J., Alberola, C. \& Brito, J. 2007a. Foraminíferos holocenos de tres sondeos de la Albufera de Valencia (Valencia, España). XII Reunión Nacional de Cuaternario, Ávila, 83-84.

Usera, J., Alberola, C. \& Brito, J. 2007b. The last foraminiferal association in the coastal lagoon of the Albufera of Valencia (Valencia, Spain). Simposio Internacional de Ciencias del Mar. Simposio GLOBEC-IMBER, Valencia, p. 52.

Usera, J., Alberola, C., Guillem, J. \& Brito, J.M. 2012. Foraminíferos de la albufera cuaternaria de Xeraco (Valencia). XXVIII Jornadas de la Sociedad Española de Paleontología, València-Sóller, 115-117.

Vénec-Peyré, M.T. 1983. Étude de la croissance et de la variabilité chez un foraminifère benthique littoral Ammonia beccarii (Linné) en Méditerranée occidentale. Cahiers de Micropaléontologie, 2, 1-31.

Viñals, M.J., Belluomini, G., Fumanal, M.P., Dupré, M., Usera, J., Mestres, J. \& Manfra, L. 1993. Rasgos paleoambientales holocenos en la bahía de Xàbia (Alicante). In: Estudios sobre Cuaternario (eds. Fumanal, M.P. \& Bernabeu, J.). València, 107-114.

Zampi, M., Foresi, L.M. \& Benocci, S. 1996. Nuove osservazioni su morfologia ed ecologia di Miliammina fusca (Brady) e Discorinopsis aguayoi (Bermúdez) rinvenuti in una vasca termale di Montecatini Terme (Pistoia). Atti Società Toscana di Scienze naturali, 103, 17-25.

Zaninetti, L. 1984. Les Foraminifères de Bras del Port (Santa Pola, Espagne), avec remarques sur la distribution des Ostracodes. Revista d'Investigacions Geològiques, 38/39, 123-138. 